\title{
The Mosaic that Never Was. Tesserae and Raw Material for an Unlaid Mosaic Floor in Trimithis (Dakhla Oasis, Egypt)
}

\author{
Asla Yapılmayan Mozaik. Trimithis’te İşlenmemiş Bir Mozaik Zemin için \\ Hammadde ve Döşeme Taşları (Dakhla Vahası, Mısır)
}

\author{
Marina M. S. NUOVO* - Silvia PRELL**
}

(Received 20 December 2019, accepted after revision 17 August 2020)

\begin{abstract}
In 2012, the international team of the archaeological expedition at Amheida, under the primary sponsorship of the Institute for the Study of the Ancient World (ISAW, New York University), found a large amount of pristine mosaic tesserae in the Roman polis of Trimithis, the modern Amheida (Dakhla Oasis, Upper Egypt). The tesserae were recovered in a room that was part of a bath complex that was under renovation when it was suddenly abandoned at the end of the $4^{\text {th }}$ century AD. The tesserae, more than 20,400 in number, were made of limestone, sandstone and, in a very small percentage, of recycled pottery, showing four different colours: white, yellow, dark grey/black and dark red. They must be considered as the first evidence for a mosaic in the Egyptian oases.
\end{abstract}

The aims of this paper are to present the finding context, the tesserae and their manufacturing and, finally, to display parallels with comparable discoveries.

Keywords: Roman Egypt, Dakhla Oasis, Trimithis, mosaic tesserae, mosaic workshop.

\section{Öz}

2012 yılında, Antik Dünya Araştırmaları Enstitüsü (ISAW, New York Üniversitesi) ana sponsorluğunda Amheida arkeolojik araştırmasını yürüten uluslararası bir ekip, Roma şehri olan Trimithis günümüz Amheida'sı (Dakhla Vahası, Yukarı Mısır) içinde büyük miktarda bozulmamış mozaik tesseraları buldu. Mozaik tesseralar, IS 4. yüzyılın sonlarında yenilenme sürecinde iken aniden terk edilmiş olan hamam kompleksinin parçası olan bir odada bulunmuştur. Sayısı 20.400'den fazla olan mozaik tesseralar, kireçtaşı, kumtaşı ve çok küçük bir oranda geri dönüşü̈rülmüş seramikten yapılmış olup, dört farklı renk göstermektedir: Beyaz, sarı, koyu gri / siyah ve koyu kırmızı. Bunlar, Mısır vahalarındaki mozaik varlığı açısından ilk kanıt olarak görülmelidirler.

Bu makalenin amacı, buluntu kontekstini, mozaik tesseraları ile bunların üretimini sunmak ve son olarak, karşılaştırılabilir keşiflerle paralellikler sergilemektir.

Anahtar Kelimeler: Roma Dönemi Mısır, Dakhla Vahası, Trimithis, mozaik tesseralar, mozaik atölyesi.

* Marina Maria Serena Nuovo, PhD, Direzione Regionale Musei Dell' Abruzzo (Ministero per i Beni e le Attività Culturali, Ministry of Cultural Heritage), via G. Ungaretti 10, 70056 Molfetta (BA), Italy. (ID https://orcid.org/0000-0003-1228-3442. E-mail: marinamariaserena.nuovo@beniculturali.it / marina.nuovo80@gmail.com

** Silvia Prell, PhD, Institut für Orientalische und Europäische Archäologie der Österreichischen Akademie der Wissenschaften, Hollandstraße 1113,1020 Wien, Austria. (iD https://orcid.org/0000-0001-7797-6026. E-mail: Silvia.Prell@oeaw.ac.at/silvia.prell@gmail.com 


\section{Introduction (MMSN)}

Dakhla Oasis ${ }^{1}$, part of the modern New Valley Governorate, is located in Upper Egypt, in the Western Desert or Libyan Desert, about $800 \mathrm{~km}$ South of Cairo and $500 \mathrm{~km}$ West of Luxor (Fig. 1). In ancient written sources it is mentioned as the Inner Oasis. Together with the Oasis of Kharga, named the Outer Oasis and situated circa $180 \mathrm{~km}$ further East, it was referred to as the Great Oasis, the Oasis Megale (Laudenbach 2015: 229 note 9, commenting Strab. 17, 1, 42). The Arabic place name is, in fact, a translation of the Greek one, probably a translation itself of the ancient Egyptian toponym, describing the internal part of a humid and warm depression (Kaper 2015: 21; Laudenbach 2015: 114 note 20, commenting Strab. 17, 1.5).

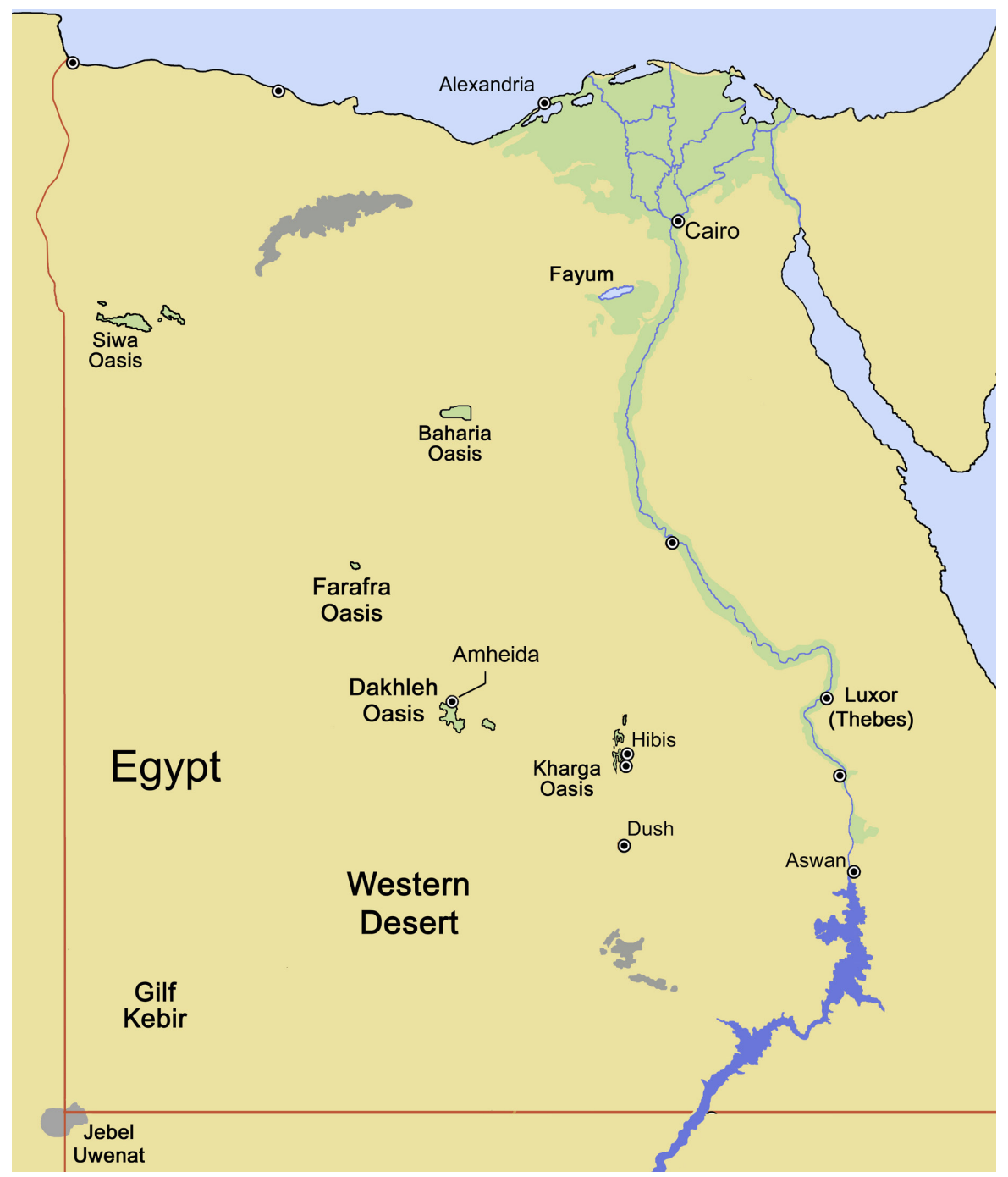

From a landscape point of view, the oasis lies in a depression bordered on the North and in part on the East by a steep escarpment, about $300 \mathrm{~m}$ high (Brookes 1994: 529) and circa $250 \mathrm{~km}$ long, broken into a number of promontories (Sefelnasr 2007: 96). The upper face consists of limestone formations, while the lower part owes its origin to the exposure by erosion of the Nubian Sediments, which consist of alternations of clays, shales, sands and sandstones (Paver Pretorius 1954: 49) $)^{2}$.
Figure 1

Map of Egypt with the location of Dakhla and Kharga Oasis, in the Western Desert (courtesy of Martin Hense).

2 For recent geomorphology studies see, for example, Brookes 1994: 529; Waldhoff et al. 2008: 12011202. 
Natural groundwater hot springs emitting iron-rich water - a fundamental resource for life and for any economic activity in every occupation period - characterise the oasis landscape (Brookes 1994: 529)3).

The archaeological potential of the oasis was recognised during the first explorations carried out at the beginning of the $19^{\text {th }}$ century, but systematic research started only in the 1970s. In 1978 the Dakhleh Oasis Project (DOP) was created, through cooperation between Anthony Mills (University of Toronto and the Royal Ontario Museum) and Geoffrey Freeman (Canadian Society for the Study of Egyptian Antiquities). In about 10 years, by means of topographic and surface surveys (Davoli 2015a: 13), the DOP identified more than 500 archaeological sites of different types and dating. Among these, the multilayered polis ${ }^{4}$ of Trimithis ${ }^{5}$ is situated about $2 \mathrm{~km}$ South of El-Qasr, in the north-western part of the oasis. The ancient name was already known from documents - papyri, ostraka and wooden tablets - found in Kellis (Bagnall 1997: 73; Bagnall - Kaper 2015: 5), modern Ismant el-Kharab, a Roman settlement located in the SouthEast of the oasis, on the route to Kharga ${ }^{6}$.

Trimithis was connected to a $3^{\text {rd }}$ to $5^{\text {th }}$ century AD imperial fort, home base of the ala I Quadorum and other units, recently identified at el-Qasr (Ast - Bagnall 2015: 2; Kucera 2016: 305-316). It was located about $25 \mathrm{~km}$ North-West of the ancient capital of the oasis, Mothis, modern Mut.

From 2004, Trimithis has been systematically excavated by an international team directed by R.S. Bagnall from Columbia University (2004-2008) and New York University (2009 to present). Since 2005, P. Davoli, (Salento University, Lecce, Italy) has been the archaeological field director ${ }^{7}$. One author of this paper acted as small finds registrar (M.M.S. Nuovo, 2006-2008 and 2011 to present) and the other as senior archaeologist (S. Prell, in the seasons 2010-2014). The Institute for the Study of the Ancient World (ISAW, New York University) is, at present, the main sponsor.

Topographic surveys in the area of Trimithis were carried out in 2005-2013 and were fundamental in defining the extent of the city and identifying different residential districts (Fig. 2).

The last phase of occupation of the city can be dated to the third quarter of the $4^{\text {th }}$ century $\mathrm{AD}$ and there is no evidence of systematic and organised re-occupation during later periods. The reasons for the abandonment are still ambiguous and under study.

Earlier phases of occupation are documented in the area of the temple, where layers dating from the Old Kingdom were reached by the deep pits illegally excavated by stone robbers and by residents looking for sebbakh, a fertiliser consisting of mud brick debris and organic material contained within the archaeological strata.

3 The natural springs have been multiplied by deeper artificial wells, dug near settlement sites in the course of the centuries. Until the 1930 s the water coming from the shallow wells had an average temperature of $28^{\circ} \mathrm{C}$, while from the deep wells it was of $33^{\circ} \mathrm{C}$ (Paver - Pretorius 1954: 69-70). Today the temperature of the artificial deep wells is between $38^{\circ}-40^{\circ} \mathrm{C}$.

4 "In Egypt, the polis system was a late arrival, beginning with Septimius Severus and fully implemented in the $4^{\text {th }}$ century AD" (Nielsen 1990: 95 note 1).

5 DOP site no. 33/390-L9-1 (Report 2004: 1).

6 During the excavations in Trimithis itself the identification of the site was confirmed by numerous ostraka mentioning this city name (Bagnall - Ruffini 2012: texts nos. 249, 250, 262, 269, 273, 276, 290, 301, 309, 314; Ast - Bagnall 2016: texts nos. 490, 493, 498, 500, 503, 510, 532, 551, 741, 837).

7 The directory of the NYU archaeological excavation at Amheida and the database are available at the web site http://www.amheida.org; accessed on 09 January 2019. 


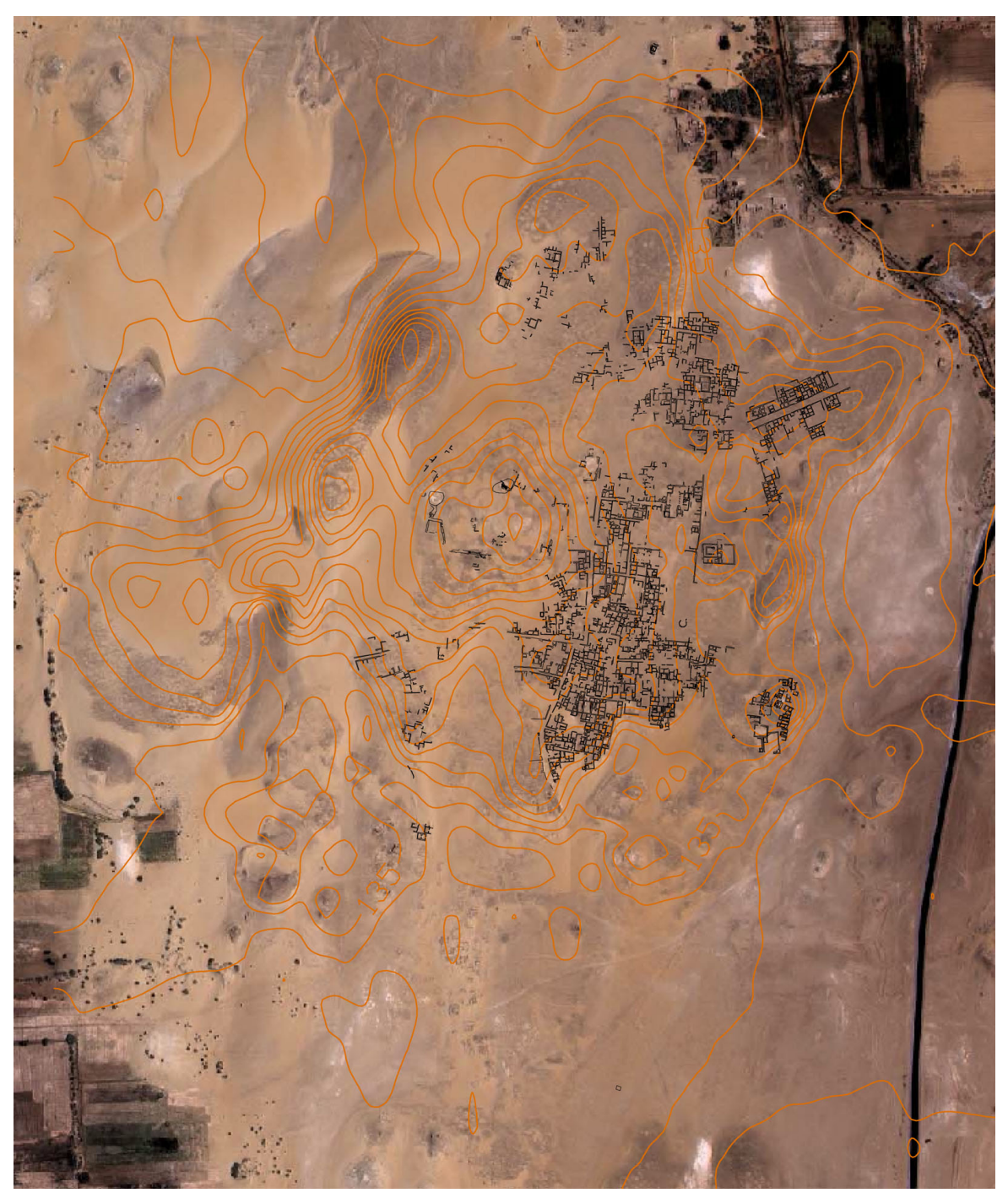

To date, the stratigraphic excavations have uncovered three houses: B1 - the socalled house of Serenos ${ }^{8}$, in Area 2, B2 in Area 1 (Boozer 2015) and B10 in Area 8 (Bagnall et al. 2017: 197-204); a school of Greek literature and rhetoric, B5, in Area 2 (Davoli - Cribiore 2010: 73-87; Cribiore - Davoli - Ratzan 2008: 170191); a public bath, B69 ${ }^{9}$ in Area 2 with a previous phase called B3 (Davoli 2017: 202-204); a church, B7, in Area 2 (Aravecchia et al. 2015: 21-43); an Egyptian temple dedicated to the god Thoth (in Area 4) and three streets adjoining the buildings (Fig. 3). Three necropoleis, to the North, East and South of the urban area were also identified, but so far not further investigated ${ }^{10}$.

The public bath known as Building 6 (from now on B6, Fig. 4) has been investigated since 2010 , but is still not completely excavated. It is the last phase, dated to the 360 s, of an older large public bath (B3) that was partly demolished and occupied by new buildings (the house of Serenos B1 and school of rhetoric B5) to the

8 The publication of the house of Serenos and two adjoining streets, S2 and S3, is in preparation and includes a volume on pottery by C. Caputo (Caputo 2020), a volume on architecture and stratigraphy by P. Davoli and a volume on small finds by M.M.S. Nuovo. For the ostraka see Bagnall - Ruffini 2012.

9 For the ostraka see Ast - Bagnall 2016; for the architecture of the building see Davoli 2017: 195-202.

10 A complete bibliography on Trimithis is available at: https://www.amheida.org/index. php? content $=$ publications, last access 09/01/2019.
Figure 2

The site of Trimithis, near the modern village of Amheida. The latter is situated in the upper right corner of the image. 
Figure 3 Map indicating the buildings so far excavated.

Figure 4 Plan of the final form of the baths (after Davoli 2017: 80,

fig. 63).
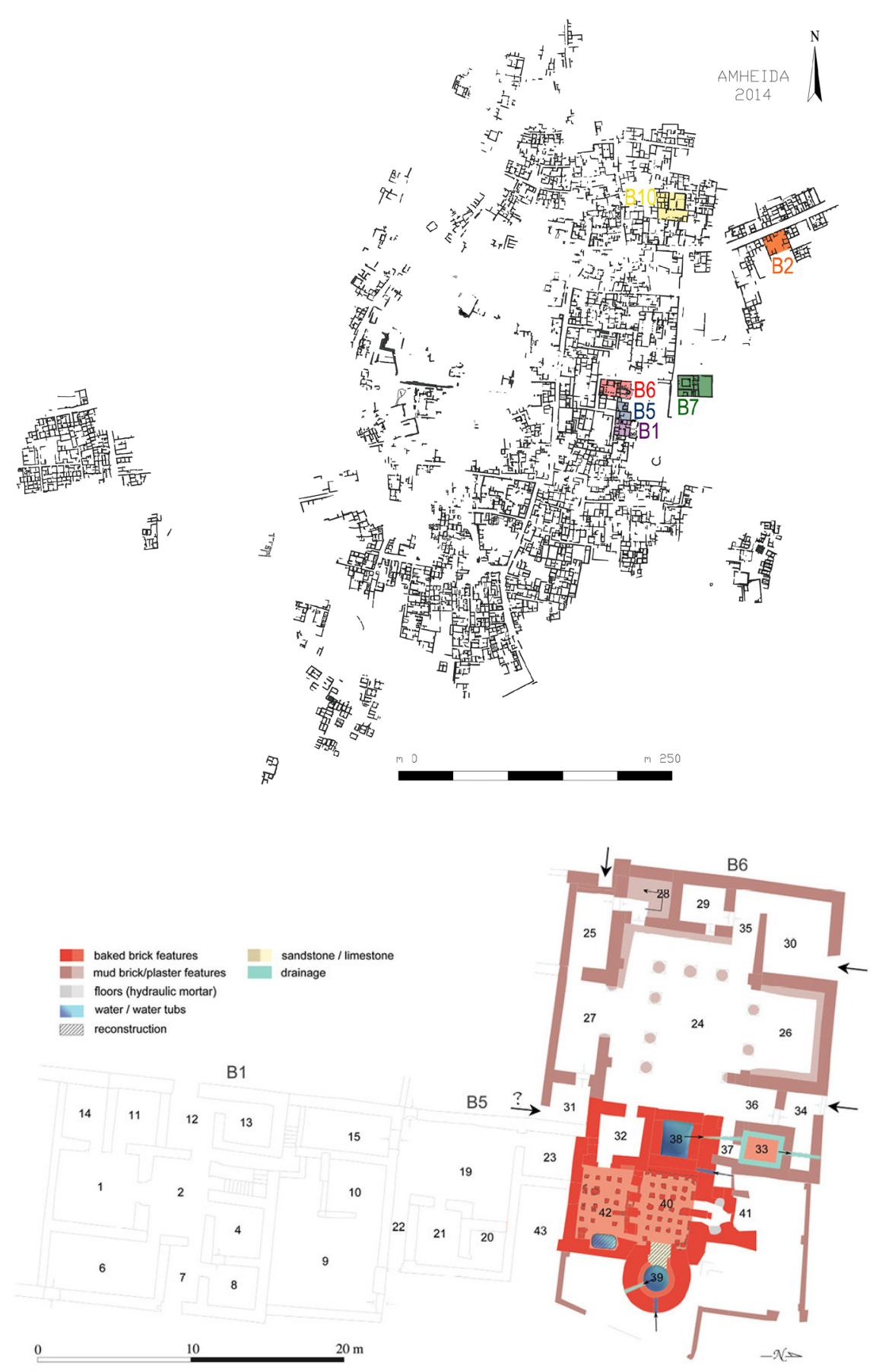

South and partly renovated to the West. B6 was abandoned while undergoing major renovations. It has been the subject of thorough studies conducted by $\mathrm{P}$. Davoli (Davoli 2015b: 76-86), archaeological field director of the excavation at Amheida, who has recently published a preliminary report, offering functional interpretations of the individual rooms, according to architectural peculiarities and stratigraphy (Davoli 2017: 193-220) ${ }^{11}$.

11 For details related to the architecture and the different phases of the bath Davoli's publication must be consulted. 
The aim of this paper is to draw attention to a unique find in Dakhla Oasis, dating to the $4^{\text {th }}$ century AD: more than 20,400 pristine mosaic tesserae, recovered in one of the rooms of the later phase of the public bath. The description and analysis of the room where this discovery was made and of the tesserae will be presented in the following paragraphs.

\section{B6, A Public Bath Under Renovation (SP)}

The excavation of B6, located in area 2, started in 2010 under the supervision of R. Casagrande-Kim and P. Davoli. The building drew special interest, as already without excavation it became clear from the visible architecture, which was not completely covered by sand, that it consisted of several rooms showing different sizes and layouts. Most interesting was the layout of the main room (Room 24, Fig. 5) equipped with two rows of columns, one running North-South and the other one running East-West.

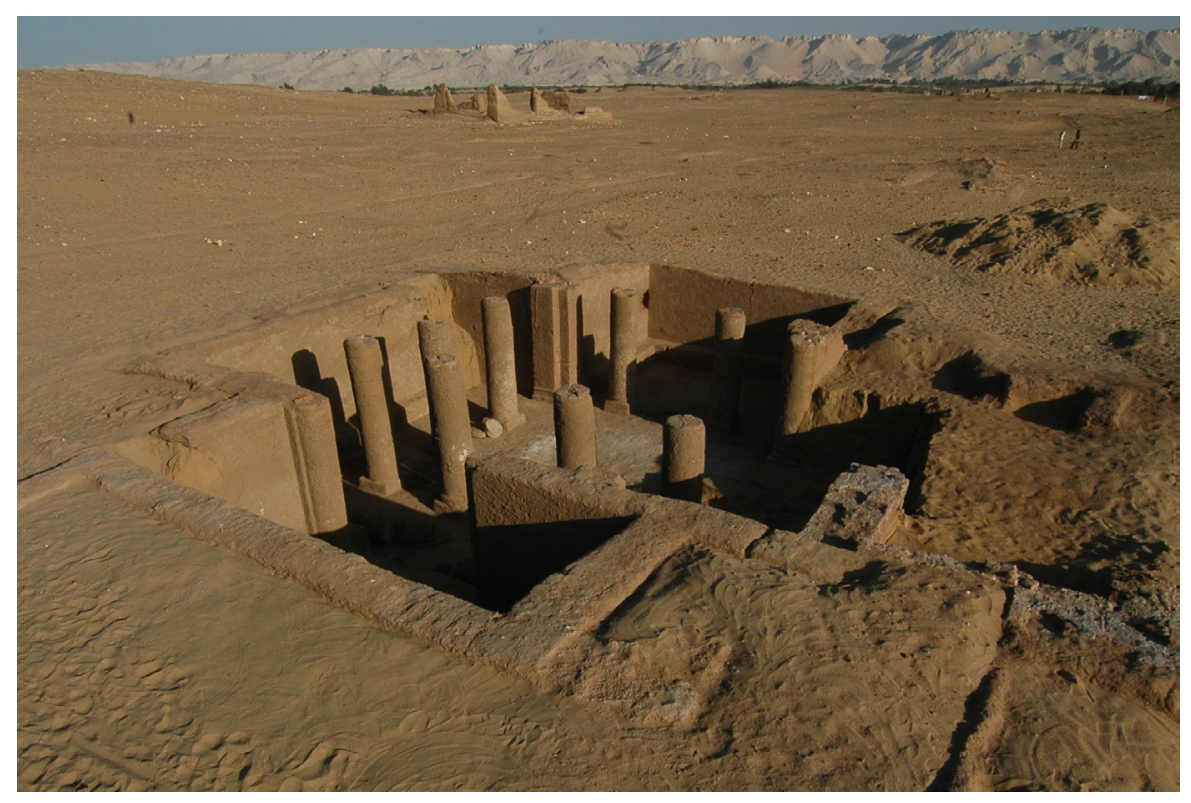

The latest mud floor level rested upon an earlier floor, plastered with lime and was - except for the collapse of a burned roof in Room 24 - found to be exceptionally clean, more or less not revealing any other finds ${ }^{12}$.

In 2012-2014, excavation was resumed in the western, southern and eastern wing of the building under the supervision of P. Davoli, M. Bruineberg and S. Prell. One of the questions concerning B6 was related to whether the Roman thermae (B3) - found underneath the house of Serenos (B1) and the school (B5) in former campaigns and belonging to an earlier phase of occupation (Davoli 2012; Davoli 2017: 202-204) - once extended further North, and if associated remains were also underlying B6. It became clear during this and the following seasons that B6 indeed once formed a part of the former thermae after a phase of abandonment (Davoli 2017: 197-199, 208-210 fig. 1-3).

B6 underwent two phases of renovation, the first one (phase 4 a, Davoli 2017: 194-195) manifesting itself clearly in the western wing of the building formed by three rooms (Room 28-30) and a passageway (Room 35) connecting the central columned hall (Room 24) with Rooms 29 and 30. Rooms 28 and 29 are of
Figure 5

Room 24, equipped with two rows of columns, during the excavation in 2010. SE corner view. 
comparable size, while Room 30 is considerably bigger and also provides access to the street North of B6, while the other two rooms were accessible only from inside the building. Both rooms once provided access to the neighbouring rooms via separate doors once connecting Room 28 and 29 with the columned hall Room 24. During the first renovation phase these doors were blocked off with walls built within the former doorframes and benches set in front of them. That those blockings were plastered from the outside shows in addition to the newly built benches that the building itself was still in use (Davoli 2017: 197). This blocking of doors is astonishing, however, especially as Room 28 was equipped with a stairwell leading to a roof top or second storey, now made inaccessible.

In Room 30 the original mud floor (FSU 123$)^{13}$ was completely lost and only preserved in a small patch still attached to the southern wall (FSU 23). Partly covering the former floor, a layer came to light (DSU 49, see below paragraph $3.1)^{14}$, which contained thousands of tesserae (see below paragraph 3.2), though it became soon evident that the room itself never was equipped with a mosaic floor.

In the north-eastern part of the building (Room 33, Fig. 4) a channel system belonging to a latrina was discovered, similar to the one already found underneath B1 (Davoli 2017: 202-203, 218 fig. 12).

East of the main pillared hall (Room 24), a round room (Room 39, Fig. 6) probably used as an immersion basin (Davoli 2017: 201-202, 205), was recovered. This room is a central feature in the bath: it is a pool-like structure with a surrounding bench on the inside, in which water entered from a pipe from the south and flowed out by means of a pipe to the East.

A round feature (Room 39), probably used as an immersion basin. E side view.

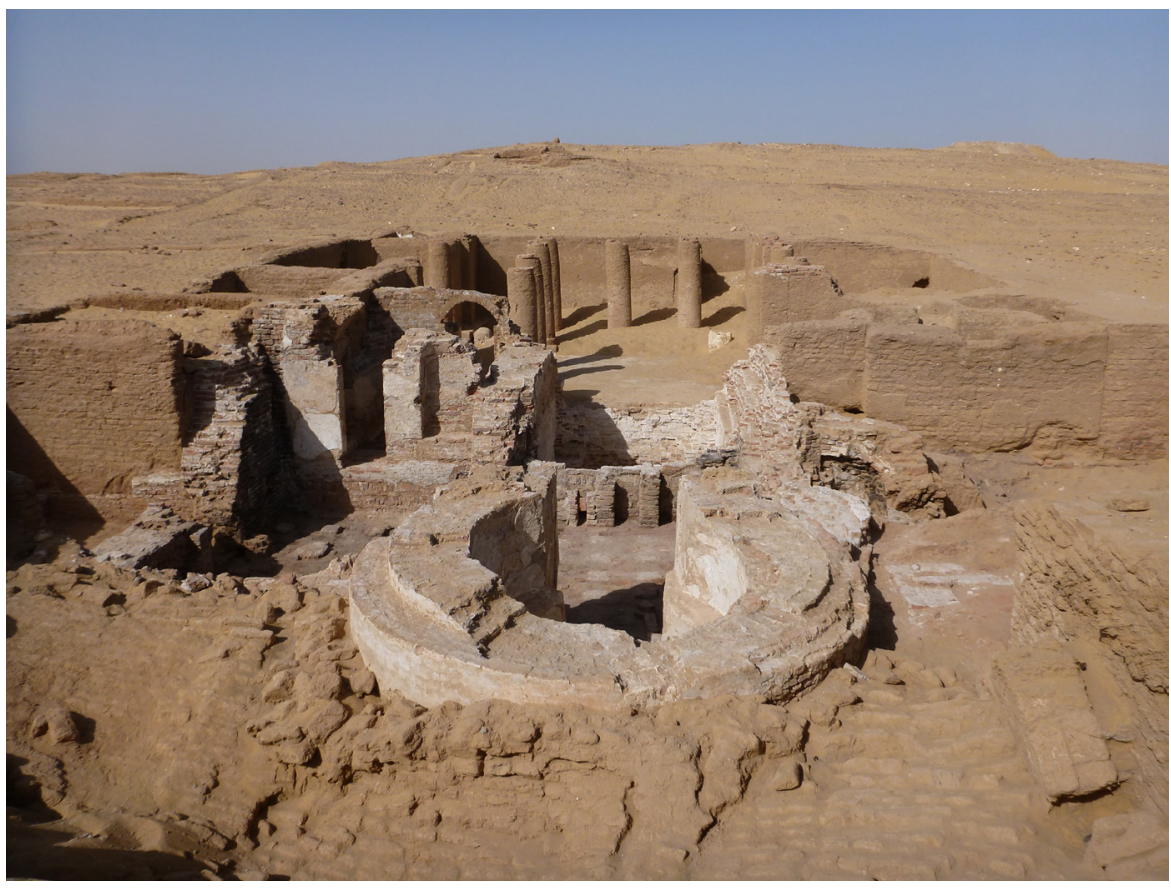

All the walls and rooms excavated in the eastern part of B6 were built from baked bricks and had been heavily spoliated to recover building material. Unfortunately, the destruction in certain areas was immense. Nevertheless, the kinds of rooms and features found clearly indicate that they were once part of a thermae building.

13 FSU $=$ Feature Stratigraphic Unit.

14 DSU $=$ Deposition Stratigraphic Unit. 
The large room west of the possible immersion basin was equipped with a hypocaust below floor level (Room 40, Fig. 4). The floor and the rising walls of the room itself were not preserved; only some of the pillars sustaining the former floor survived. The floor and walls of the hypocaust were all blackened by soot, and the brickwork of the pillars was partly glazed and melted from the heat they were exposed to for a long time period. This hypocaust is connected to the South with a second one (Room 42) by means of five channels covered by vaults; in the North it was connected to a boiler room (praefurnium, Room 41).

Both rooms, Room 40 and Room 42, were probably hot dry rooms, as the suspended floor (suspensura), as far as preserved, was too thin (c. $8 \mathrm{~cm}$ thick) to support water pressure.

Room 42 was connected with the main pillared Room 24 through Room 32. This last room is also the best preserved one, up to a wall height of about 3 meters. Room 32 was the only passage from Room 24 - and the western dry area of B6 - to its eastern side, in which bathing took place (Davoli 2017: 199-200). North of this room a badly demolished pool (Room 38) is located. This pool probably opened towards Room 24 but was perhaps accessed from Room 40 (Davoli 2017: 199). Water flowed out through a sewer channel located at a lower level in the northern wall and connected with the latrina in Room 33 (Davoli 2017: 198-199).

Although the architecture in this part of B6 was in a very bad state, clear indications of a second phase of renovation could be traced. The damage to the pillars of the hypocaust in R40 and R42 had been repaired with red bricks covered in grey plaster patched into the gaps or partly rebuilding excessively decayed parts of the pillars. Between Room 40 and Room 42 some of the former channels, once providing the hypocaust with hot air from the south, were blocked off by blocking walls. Those repairs show no sign of blackening, meaning that the hypocaust never went into use again (Fig. 7). Except for the restoration of the damaged parts of the pillars of the hypocaust, the boiler room in the North underwent restoration work as well. The newly applied white mortar was never smoothed, but still showed hand and finger prints from the workmen. A batch of that mortar was also left behind on the floor of Room 42. Further doors were blocked and the blockings plastered over in the rooms still in use (door leading from Room 27 to Room 31, door leading from Room 25 to the stairwell (Room

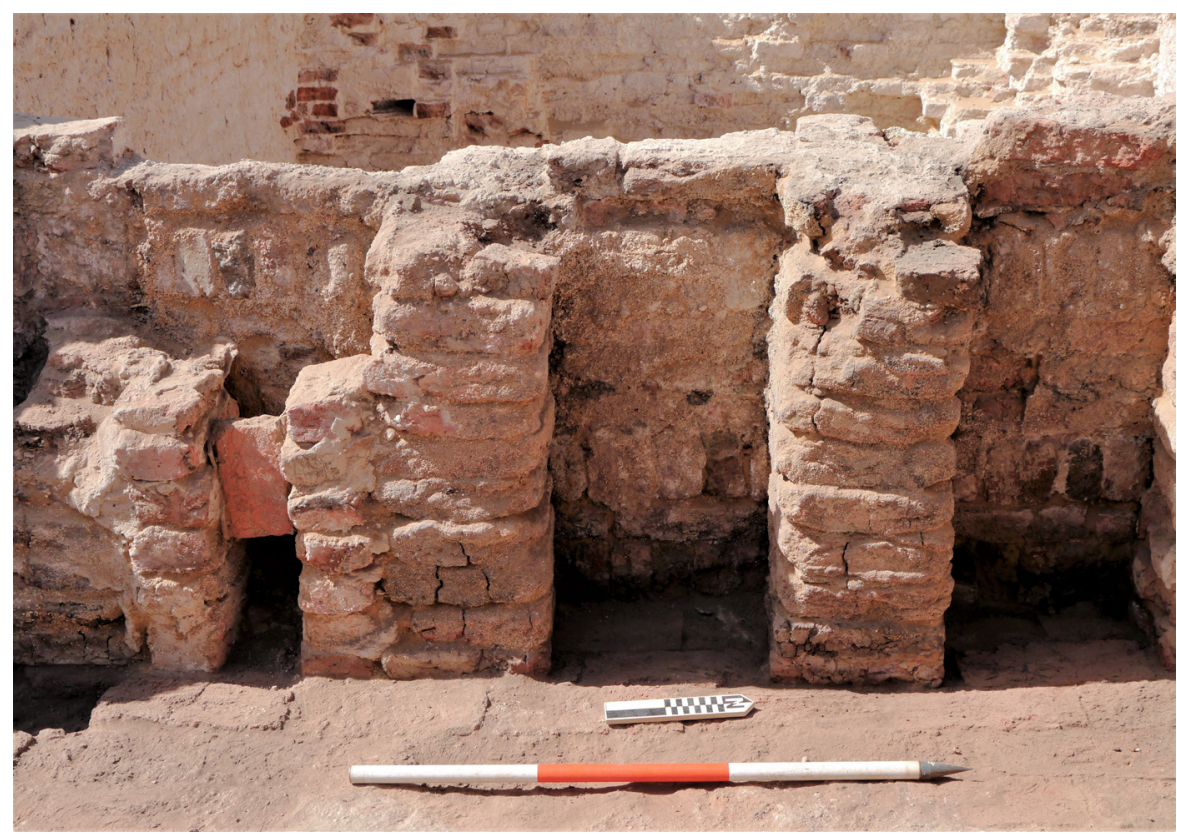

Figure 7

Repairs undertaken at the pillars of the hypocaust, showing no sign of blackening by soot. 
28), door leading from Room 29 to Room 35 and door leading from Room 34 to 36 (Fig. 4). This blocking of doors clearly shows that the effective area of the building was severely reduced in size and also the use of the second storey or rooftop was completely abandoned.

The floor of the pillared hall (Room 24) was under restoration (Davoli 2017: 196 with note 14), and Room 30 was at the same time used as a working space. The mosaic tesserae found in here in 2012 were prepared and never used. The restoration and sudden abandonment of the thermae might very well be the reason for the general lack of objects found within the building. As stated before, the building was used, abandoned, reused, restored and abandoned again during further restoration work. All features encountered in B6 can be considered as the last phase of the thermae already found to the South below B5 and B1 (Davoli 2017: 194), although reduced to a much smaller scale (Davoli 2017: 210 fig. 4).

\section{A Temporary Mosaic Workshop in Room 30}

\subsection{Room 30 (SP)}

Room 30 (Fig. 8) provides one possibility of access to B6 within its northern wall, located close to the north-western corner of the room. The entrance opened onto an adjacent East-West street. The room occupies an area of about 20.5 sq. $\mathrm{m}(4.15 \times 5.00 \mathrm{~m})$ and the rising walls are preserved to a height between 2.80

Figure 8

Room 30 with walking surface FSU 76, after extraction of tesserae layer DSU 49, SW corner view.

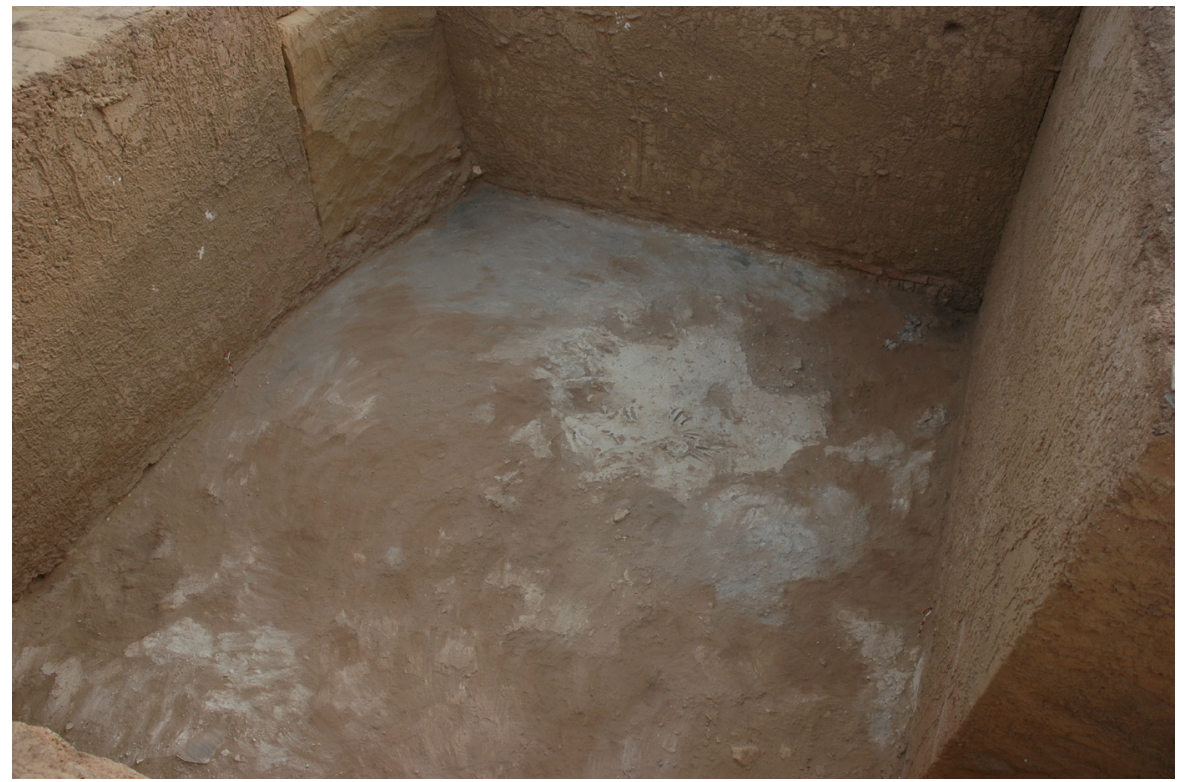

and $3.49 \mathrm{~m}$. There were no remains of a roof discernible in the layers above; perhaps it was flat, as there are no spring vaults. The wooden elements used for the roof, a precious material in an oasis environment, were probably taken away after the abandonment of the building and recycled. The walls are built from a combination of baked bricks and mudbricks ${ }^{15}$, coated with a layer of light brown mud-plaster (FSU 85) that, on the southern and northern walls and in

15 The lowest portions of the walls consist of courses of mud bricks, followed by two courses of baked brick, the lower of which is turned on edge, while the higher course is set as stretchers. Those sit on a protruding foundation made as well from a combination of baked and mud bricks. The presence of only few courses of baked bricks alternating with mud bricks suggests that these walls were not originally part of the thermae, but may have reused some of its baked bricks. 
the doorway to Room 35, is overlain by a reddish plaster (FSU 95). No proper floors were preserved; only the very last remains of the original mud floor (FSU 123) were found on the eastern edge of the door-frame ${ }^{16}$ connecting Room 30 with Room 35 . FSU 123 was abutted by the later reddish plaster. However, a sequence of walking surfaces, starting from above the former floor level (FSU 123), could be determined (Fig. 9). FSU 75 can be considered as a walking and

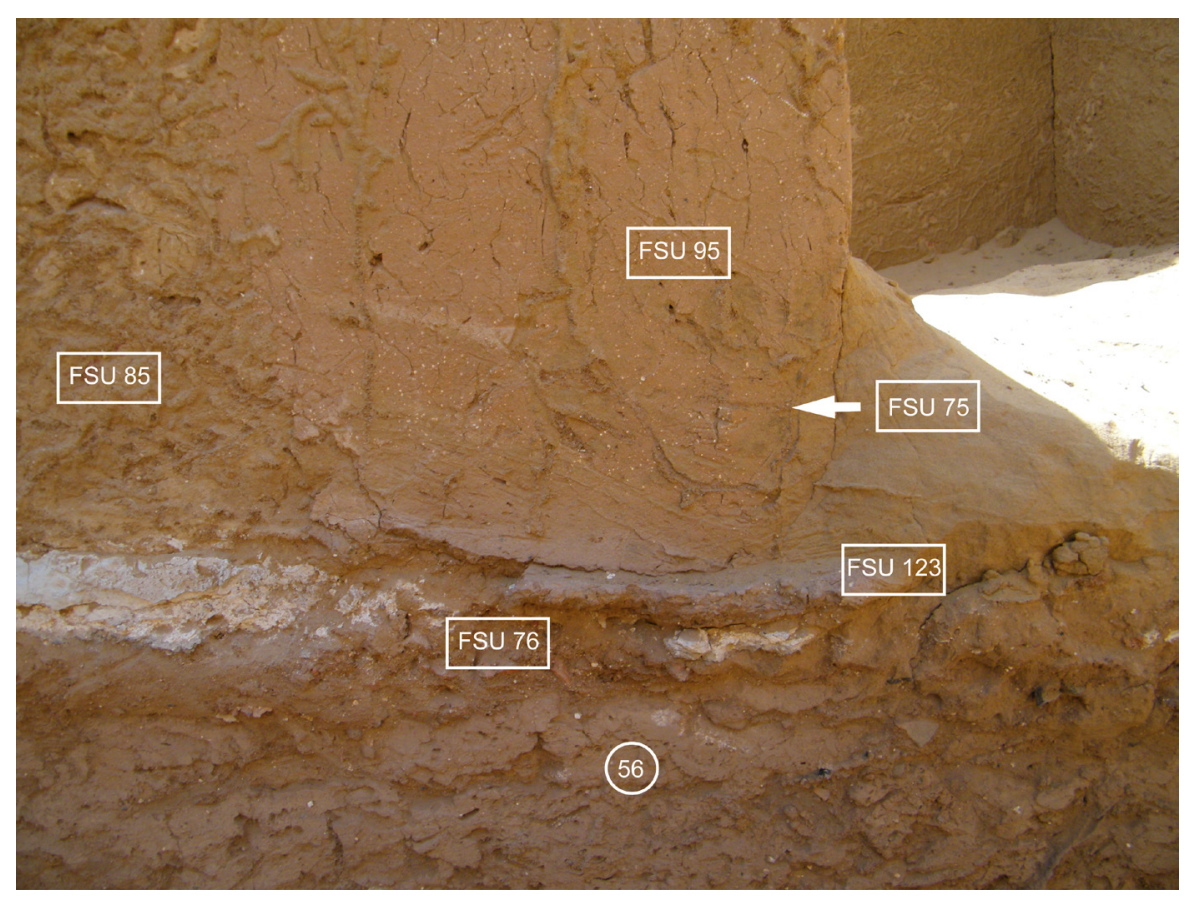

working surface and interface to DSU 49 (sandy deposit). It consists of a layer of mud-plaster irregularly spread and present in the central part of the room, prolonging until the northern wall, but not abutting the other walls. DSU 49 contained sandstone and limestone rubble, flakes and some sandstone boulders, pottery, and some mudbrick as well as baked brick pieces. The tesserae were distributed in three main clusters within this DSU (see below paragraph 3.2). Below the former floor (FSU 123) another floor layer or walking surface (FSU 76) consists of large patches of white gypsum plaster, particularly hard in some places. A depression in the south-eastern part of the room was filled with white hydraulic mortar and shows several strokes of fingers running in different directions, with unclear function (Fig. 10). In the West and in the South of the room the patches of mortar are partly abutting the wall and are also slightly running up the earlier light brown wall plaster (FSU 85) for a few centimeters. Splashes of white mortar plaster were found on all perimetral walls, sprayed on top of the earlier light brown plaster covering them. Accordingly, the room was used for the preparation of mortar and/or the latter was used to fill in an unevenness in the rubble/floor preparation layer underneath (DSU 56, equals DSU 60, Fig. 11). The floor remains FSU 123 sit directly on top of FSU 76 and FSU 123 is abutted by the later reddish wall plaster FSU 95; those cannot thus be contemporary with the tesserae production taking place in this room and can be considered as remains of the earlier phase of renovation (installation of benches and blocking of doors in Room 24, see above paragraph 2) involving
Figure 9

Sequence of walking surfaces and wall plasters in the southern wall of Room 30. 
Figure 10

A close up of the depression of FSU 76 in the south-eastern part of Room 30 filled with white hydraulic mortar showing several strokes of fingers running in different directions.

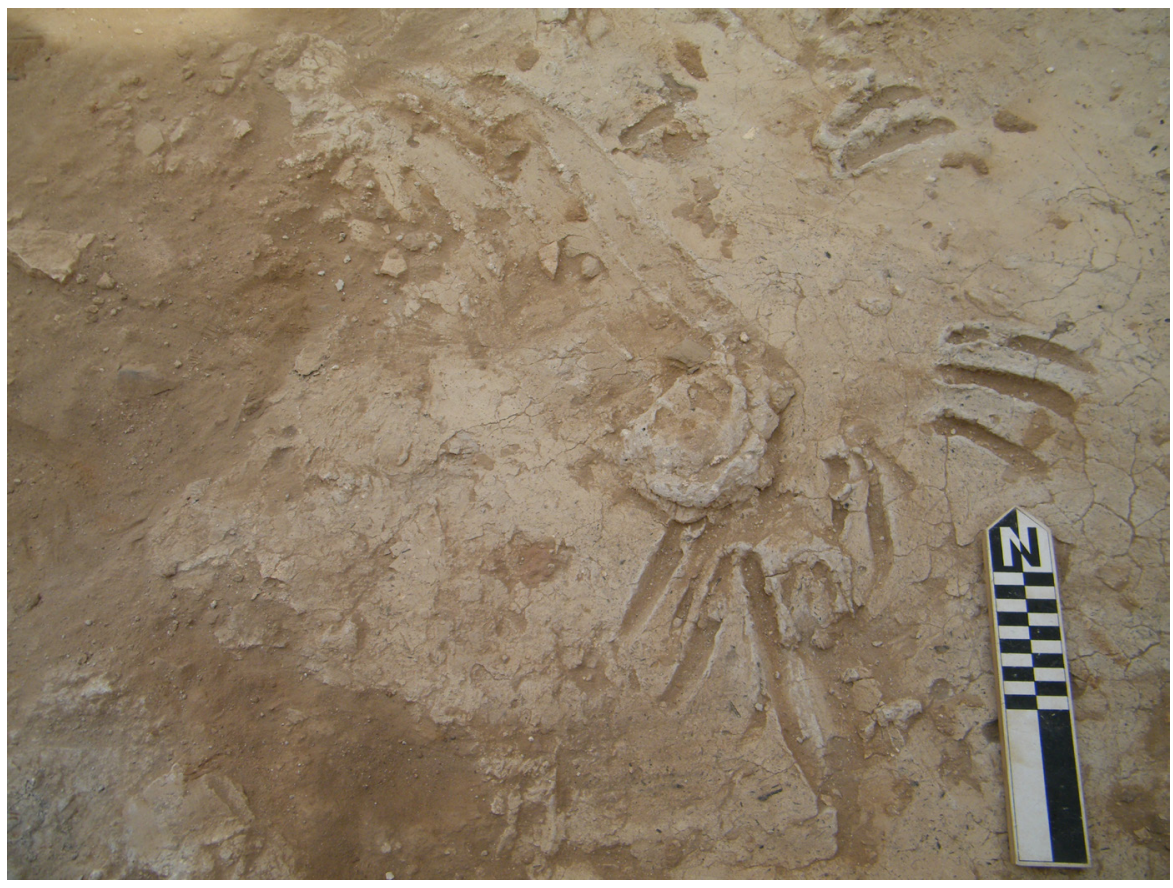

Figure 11

Sequence of layers in Room 30 as captured in the section within the door opening to the street on the North.

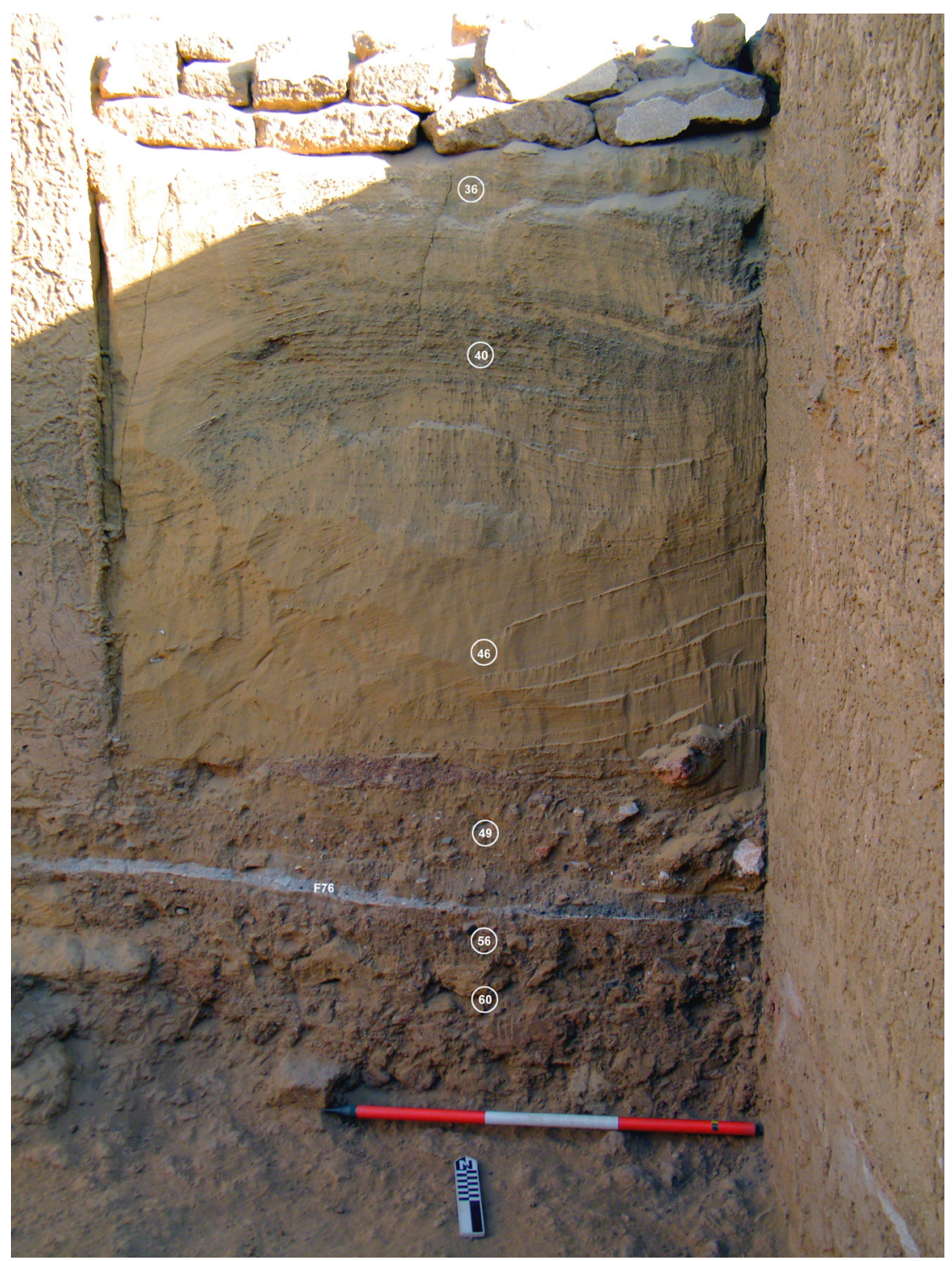


mortar plaster production ${ }^{17}$. To state the sequence again: the perimetral walls of the room were built and covered with a light brown mud plaster (FSU 85); the floor belonging to this phase is not preserved. After this, mud and gypsum mortar plaster were prepared in the middle of the room, an activity that left traces as well on the wall plaster. Ash, charcoal and gypsum were mixed with the mud mortar, as well as mud bricks. Fragments of white gypsum plaster from walls have also been collected in this area. In addition, natural gypsum stones were found in high quantity. Below the plaster preparation level was a layer of debris filling the foundation of the room. Because there was no preserved floor in between, it might be possible that these foundation debris layers were partly excavated as DSU 49.

When the plaster preparation came to an end, a mud floor was prepared in the room (FSU 123) and the walls were partly covered with a reddish mud plaster (FSU 95). Tesserae production in this room started after the floor was already destroyed, or else the floor was eradicated during their preparation. Some of the white limestone tesserae were found attached to the bottom of the earlier wall plaster FSU 85 on the northern wall FSU 44, and most probably got stuck there as no floor was present anymore. A limestone mortarium found in the middle of the room should be connected to the tesserae production (see below paragraph $3.3)$.

\subsection{The tesserae (MMSN)}

In 2012, a large number of mosaic tesserae of four different colours was found in Room 30, embedded within DSU 49 and roughly grouped by colour. There was a cluster of mainly black tesserae alongside the western wall (Fig. 12) and concentrations of white ones in the south-eastern corner of the room and close to the northern wall (Fig. 13). Alongside the eastern wall F1 a group of chipped fine red-slipped ware, followed further South by a concentration of yellowish tesserae, was found (see below in more detail).

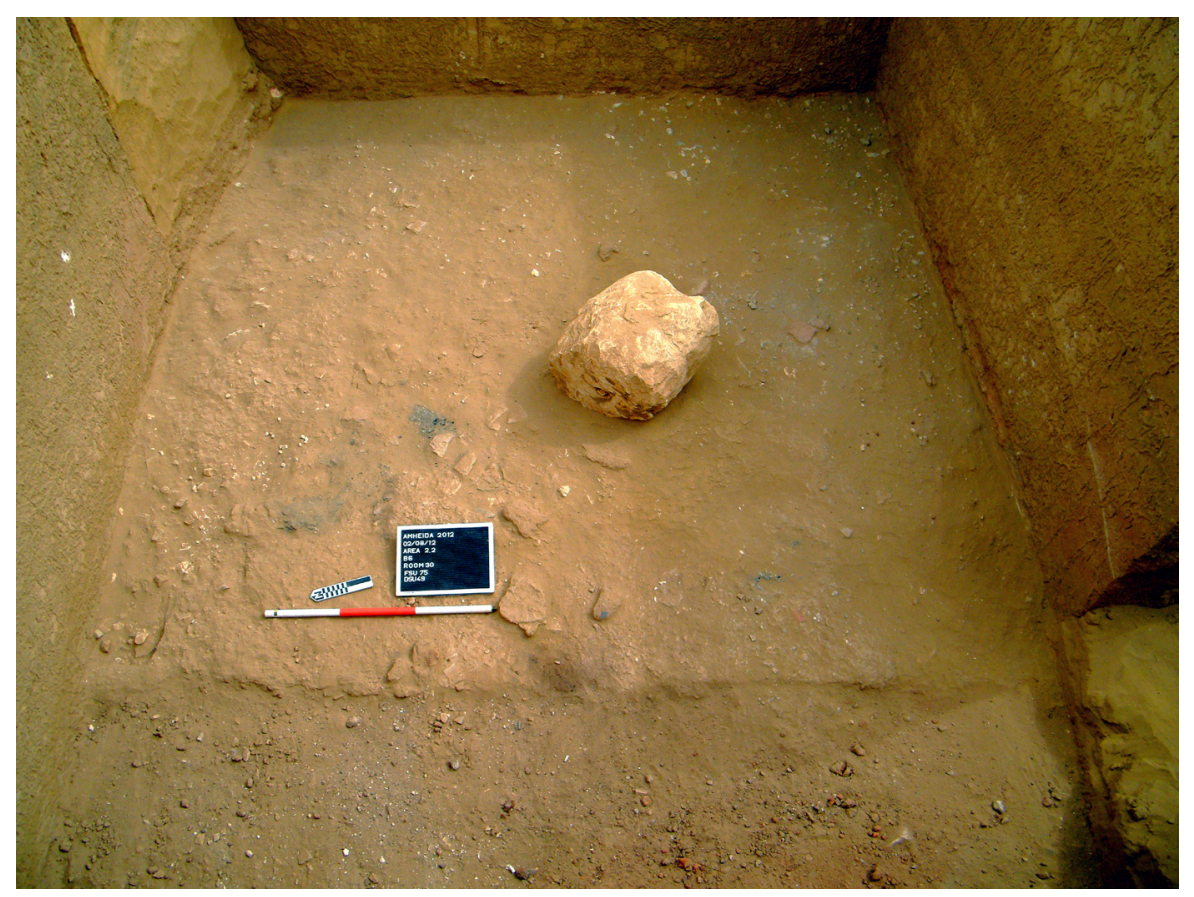

17 According to P. Davoli, Room 30 was a large space used for preparing mud-plaster and, after that, for manufacturing the tesserae (Davoli 2017: 195).
Figure 12

DSU 49 with the mortarium as found and white tesserae clustered in the SE corner of the room and along the northern wall. W side view. 
Figure 13

A cluster of mainly black tesserae alongside the western wall.

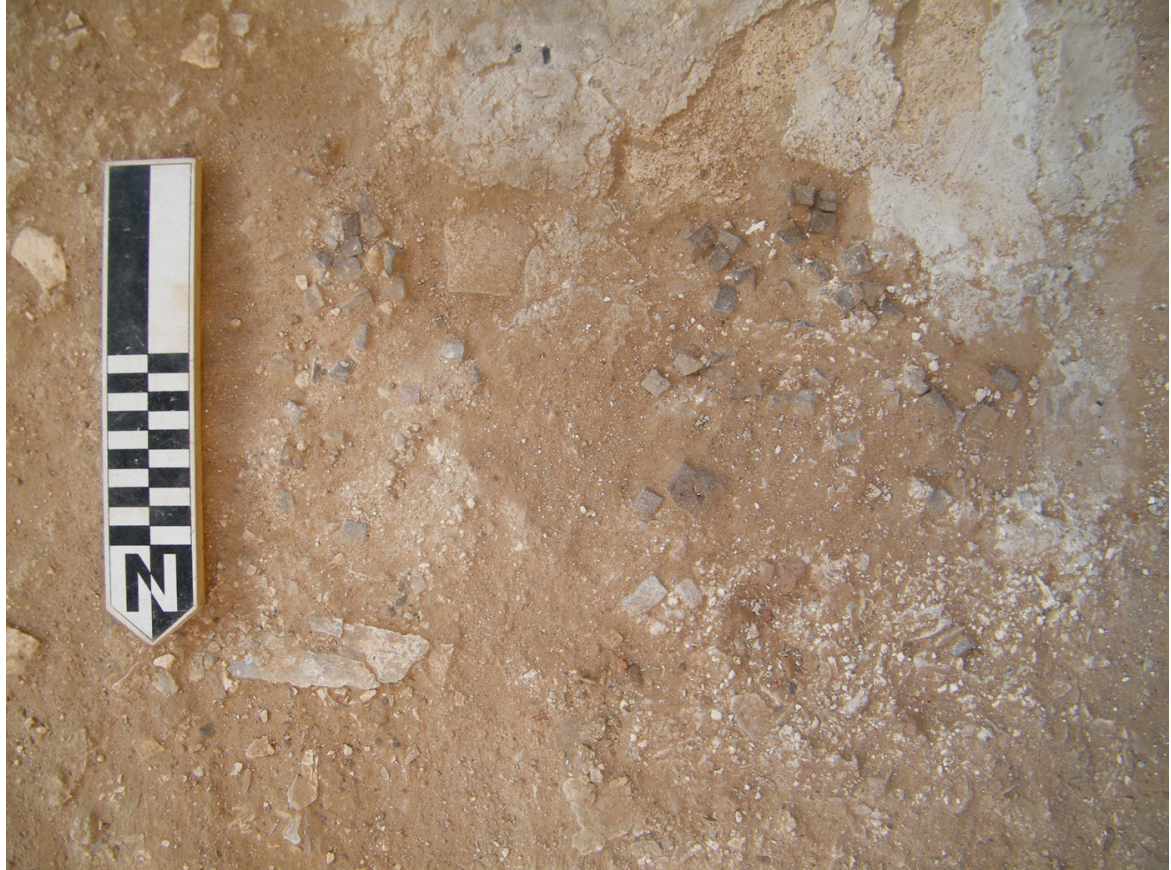

The tesserae were not counted piece by piece, but their number was estimated on the basis of their weight. Sample-groups of one-hundred tesserae of each colour were weighed and compared with the total weight of the specimen of each colour. In this way it was possible to reach an estimate number, without actually counting them. Three sizes were distinguished, according to the length of the tesserae sides: small, from 0.8 to $1.1 \mathrm{~cm}$; medium, from 1.2 to $1.4 \mathrm{~cm}$; large, from 1.5 to $1.8 \mathrm{~cm}$. The dimensions of the tesserae from Amheida are comparable to those of other mosaics dating to the $4^{\text {th }}$ century AD (for example, Wootton 2012b: 148 table 1; Merrony 2013: 53, 61-66 tables 11-12).

White tesserae are the most numerous (inv. no. 15800, Fig. 14) and weigh 47.58 $\mathrm{kg}$, roughly 11,895 pieces. They are usually cubic in shape - with a few variants of parallelepiped shape - and are made of limestone of slightly different tints, varying from bright white to light yellowish and pinkish. Two different sizes, small and large, were identified.

Dark yellow tesserae (inv. no. 15798, Fig. 15) follow the white ones in quantity, as there are $17.4 \mathrm{~kg}$ or approximately 4,203 pieces. They are all cubic in shape, made of sandstone and show three different sizes, small, medium and large.

Dark grey/black tesserae (inv. no. 15797, Fig. 16), $11.5 \mathrm{~kg}$ or roughly 3,286, are also made of sandstone and, like the dark yellow ones, are all cubic in shape and occur in three sizes.

Dark red tesserae (inv. no. 15799, Fig. 17), $3.8 \mathrm{~kg}$ or approximately 1,047 pieces, are also made of sandstone and are mostly cubic, with few examples showing parallelepiped shape. Three sizes, small, medium and large, were identified.

In total $80.28 \mathrm{~kg}$ of tesserae were recovered from Room 30, resulting in an approximate total number of 20,430 pieces. 

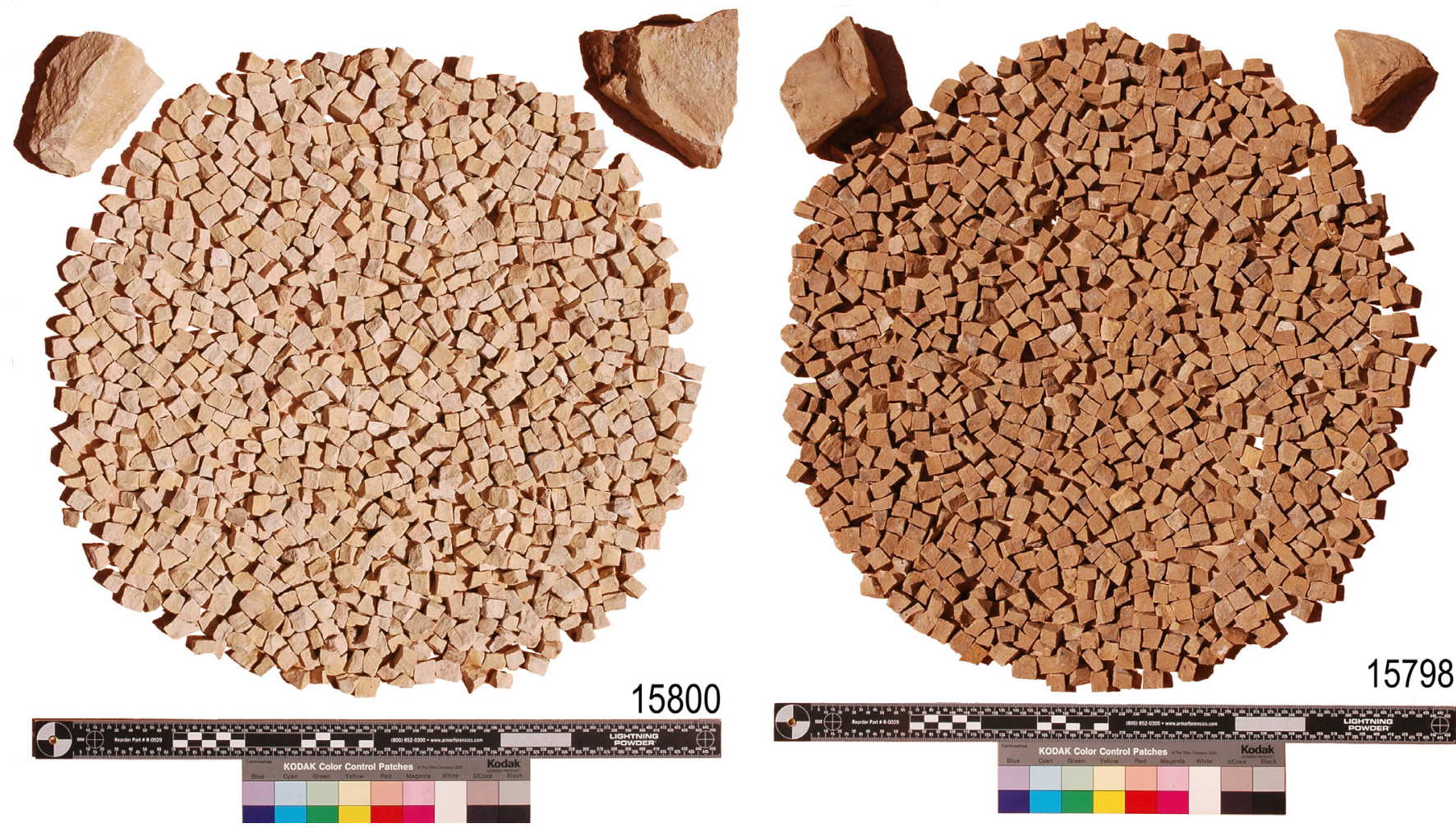

Figure 14

A sample of 100 white tesserae with part of the raw material found within DSU 49 (graphic elaboration: MMSN).

Figure 15

A sample of 100 yellow tesserae with part of the raw material found within DSU 49 (graphic elaboration: MMSN).
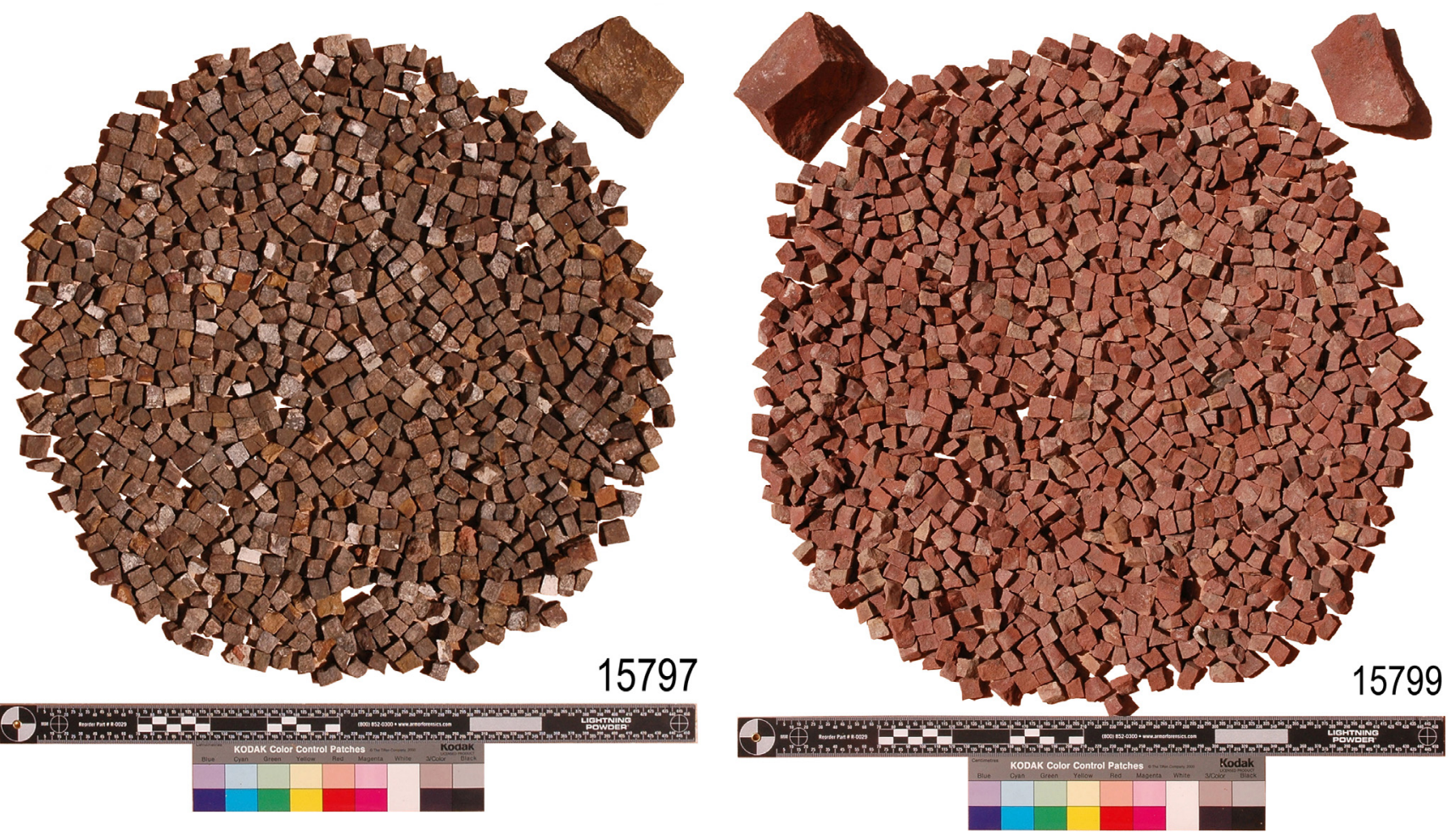

Figure 16

A sample of 100 grey/black tesserae with part of the raw material found within DSU 49 (graphic elaboration: MMSN).
Figure 17

A sample of 100 red tesserae with part of the raw material found within DSU 49 (graphic elaboration: MMSN). 
Table 1

Characteristics of the tesserae recovered in Room 30.
The listed characteristics are summarised in the following table, "Table 1".

\begin{tabular}{|c|c|c|c|c|c|}
\hline COLOUR & MATERIAL & WEIGHT & $\begin{array}{c}\text { NUMBER } \\
\text { (approx.) }\end{array}$ & SHAPE & DIMENSIONS \\
\hline white & $\begin{array}{l}\text { limestone } \\
\text { (white, light } \\
\text { yellowish and } \\
\text { pinkish) }\end{array}$ & $\begin{array}{c}47.58 \mathrm{~kg} \\
\text { (total); } \\
100 \text { tesserae: } \\
400 \mathrm{~g}\end{array}$ & 11,895 & $\begin{array}{c}\text { cubic; } \\
\text { a few with } \\
\text { parallelepiped } \\
\text { shape }\end{array}$ & $\begin{array}{c}\text { small, } \\
\text { large; } \\
\text { parallelepiped: } \\
1.1 \times 1.5 \times 1.7 \mathrm{~cm} ; \\
0.9 \times 1.2 \times 1.9 \mathrm{~cm}\end{array}$ \\
\hline $\begin{array}{c}\text { dark } \\
\text { yellow }\end{array}$ & sandstone & $\begin{array}{c}17.4 \mathrm{~kg} \text { (total); } \\
100 \text { tesserae: } \\
414 \mathrm{~g}\end{array}$ & 4,203 & cubic & small, medium, large \\
\hline $\begin{array}{l}\text { dark grey/ } \\
\text { black }\end{array}$ & sandstone & $\begin{array}{c}11.5 \mathrm{~kg} \\
\text { (total); } \\
100 \text { tesserae: } \\
350 \mathrm{~g}\end{array}$ & 3,286 & cubic & small, medium, large \\
\hline dark red & sandstone & $\begin{array}{c}3.8 \mathrm{~kg}(\mathrm{total}) \\
100 \text { tesserae: } \\
363.3 \mathrm{~g}\end{array}$ & 1,047 & $\begin{array}{c}\text { cubic; } \\
\text { only the large } \\
\text { size includes } \\
\text { parallelepiped } \\
\text { shapes }\end{array}$ & small, medium, large \\
\hline
\end{tabular}

The following pie chart "Table 2" illustrates the percentage of tesserae charted per colour.

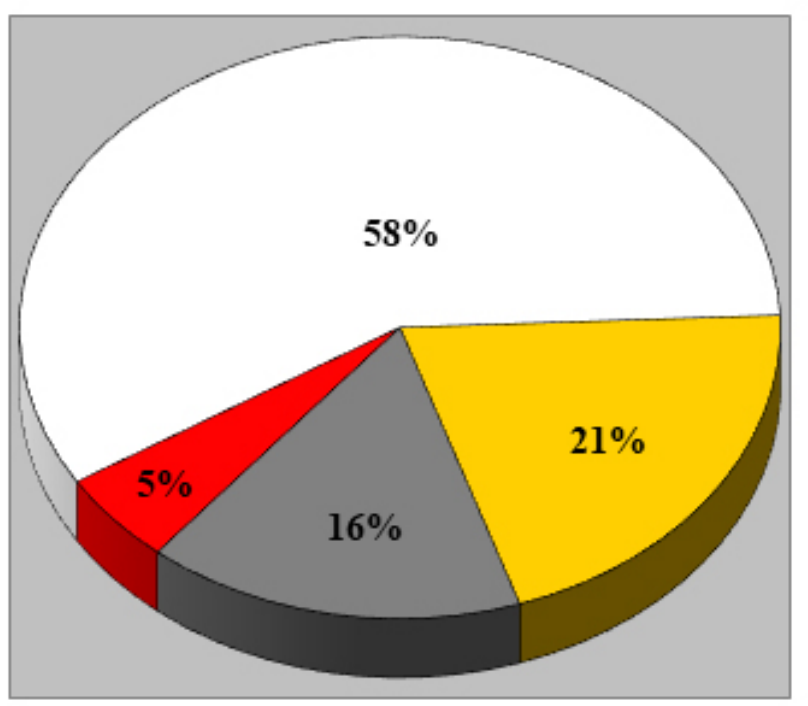

$\square$ White (11.895 tesserae)

口Dark yellow (4.203 tesserae)

口Dark grey/black (3.286 tesserae)

口Dark red (1.047 tesserae)

Table 2

Percentage of tesserae charted per colour.
On the base of the total number of tesserae found, calculating an average side of $1 \mathrm{~cm}$ for each tessera, the estimated minimum area that could be covered with them is roughly $4.30 \mathrm{sq}$. m. Obviously, this calculation cannot take into consideration the interstices, the space between tesserae, which could have had tesserae laid either loosely or tightly. Consequently, the density of the tesserae per square metre cannot be estimated, and it is not possible to determine if the work was going to be coarse, of middle or good quality ${ }^{18}$. The degree of accuracy in the mosaic work could be considered as an index of financial expenditure (Merrony 2013: 60).

18 According to M. Avi-Yonah (in Merrony 2013: 54), a coarse pavement has 4 to 20 tesserae per sq. dm, a middle quality has 20 to 30 tesserae per sq. dm and a fine work has 42 to 100 (or even 157) tesserae per sq. dm. 
Twenty pottery body sherds (inv. no. 15850, Oasis Red Slip Ware, Fig. 18), intentionally chipped into square shape, were identified within DSU 49 and interpreted as an addition to the red tesserae. Two sizes are discernible: large with a side length of $1.5 \mathrm{~cm}$ and a thickness from 0.6 to $0.9 \mathrm{~cm}$, and very large with a side length of $2.1 \mathrm{~cm}$ and a thickness from 0.7 to $1 \mathrm{~cm}$.

Ten pottery body sherds, black in colour (inv. no. 15849, fabric A1b ${ }^{19}$, Fig. 19), chipped into square shape, were also found within DSU 49 and were probably used as an addition for black tesserae. They occur in three different sizes: small $(1.8 \mathrm{~cm}$ with a thickness of $0.55 \mathrm{~cm})$, medium $(2.1 \mathrm{~cm}$ with a thickness of $0.7 \mathrm{~cm})$ and large $(2.8 \mathrm{~cm}$ with a thickness of $0.7 \mathrm{~cm})$. These fragments were concentrated along the eastern wall of the room. None of the pottery tesserae are cubic in shape and they are thinner than their counterparts made of limestone and sandstone, because their height was limited by the original thickness of the potsherds used to manufacture them. Their overall dimensions are slightly dissimilar from those of the stone tesserae, as the smallest have a side length of $0.6 \mathrm{~cm}$ and the largest of $2.8 \mathrm{~cm}$.

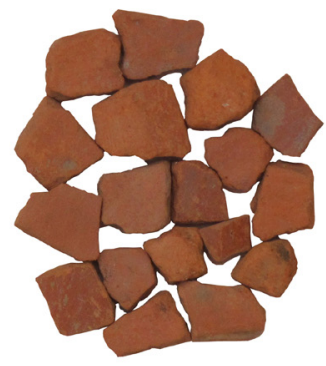

15850
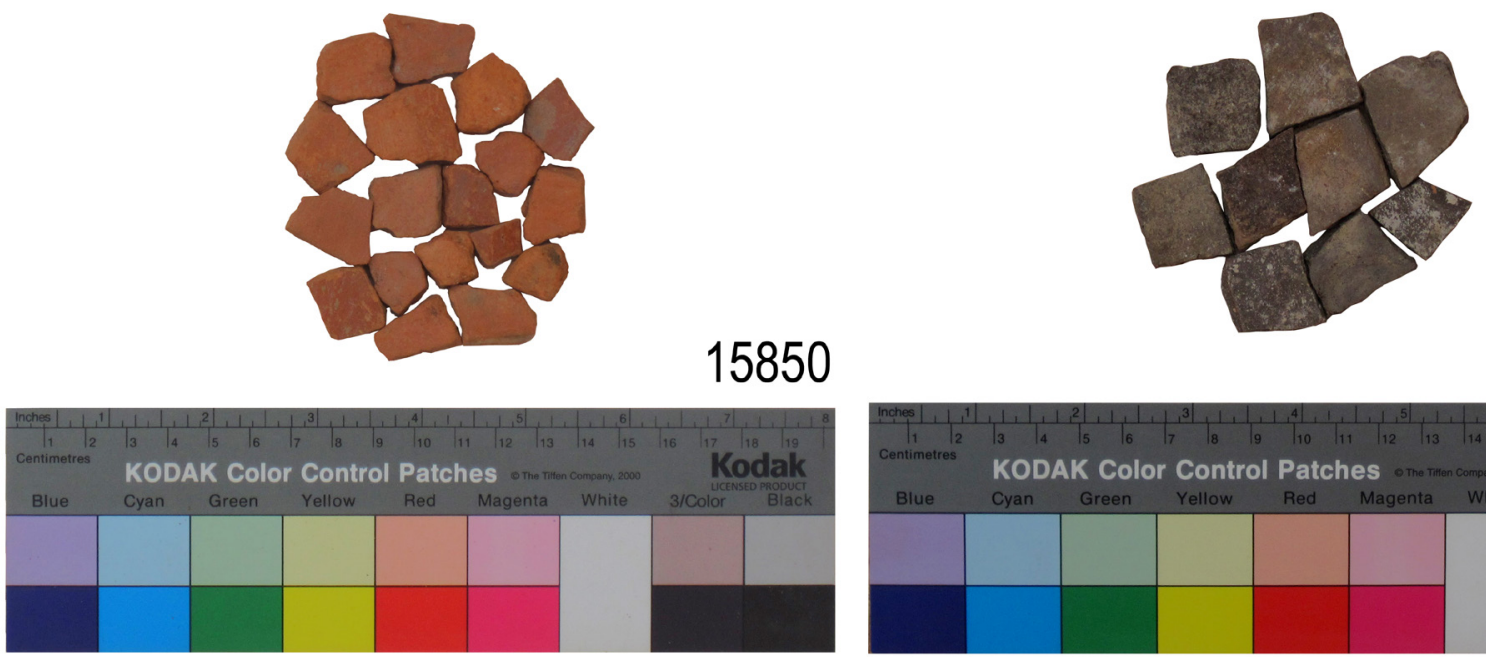

Figure 18

Oasis Red Slip Ware body sherds intentionally chipped into square shape and interpreted as an addition to the red tesserae.

Figure 19

Pottery body sherds, fabric A1b, intentionally chipped into square shape and interpreted as an addition to the grey/black tesserae.

The use of tesserae made of pottery or terracotta is well attested from the Hellenistic times (Wootton 2012a: 222 with previous references) ${ }^{20}$ throughout the Roman period. A late Roman example ${ }^{21}$, the large mosaic found in the villa at Badminton Park, not far from the city of Bath (UK) and dated to the mid to late $4^{\text {th }}$ century $\mathrm{AD}$, comprises a small number of tesserae made of orange terracotta, recycled from tiles (Wootton 2012b: 148, table 1, 149). Another $4^{\text {th }}$ century example is known from the villa of Lullingstone (Eynsford, UK), where the mosaic's border was completed by tesserae from recycled box-flue tiles (Wootton 2012b: 151). Also dating to the $4^{\text {th }}$ century, terracotta tesserae

19 A1 indicates an iron-rich fabric typical of Dakhla Oasis, sometimes with intentional blackened surfaces due to the firing process. When the surface is not blackened it is called A1a, otherwise is called A1b. For fabric identification in Dakhla Oasis see Bagnall et al. 2017: 199 note 15, with previous references.

20 Examples are known, for instance, from Delos, Rhodes, Cyrene, Palermo, Pompeii (Wootton 2012a: 222) and Diospolis Parva (Guimier-Sorbets 2019: 124). In Alexandria terracotta tesserae are also documented (Daszewski 2000: 44) since the end of the $4^{\text {th }} \mathrm{c}$. BC, for example in the "House with a rosette" ("Maison à la rosace", garden of the former British Consulate), dated 315-300 BC, where terracotta tesserae border the pebble mosaic floor of the andrōn (Guimier-Sorbets 2019: 122). Apparently, in Alexandria terracotta or ceramic tesserae were not used in the higher-quality mosaics (Wootton 2012a: 222).

21 For early Roman mosaics with terracotta tesserae see Allen - Fulford 2004: 16. 
Figure 20 An outcrop with layers of red and yellow sandstone, near Gebel Edmonstone (photo B. Bazzani).

are included in the mosaics of the villa in Castle Copse (Great Bedwyn, UK) (Kenfield 1997: 169-175). In Late Roman Phoenicia and Northern Palestine, mosaics occasionally include glazed terracotta tesserae (Merrony 2013: 54). Pottery and terracotta sherds could easily be recycled into tesserae (Wootton 2012b: 153), as the material was cheap or even costless, if collected from dumps, and is resistant enough to withstand the pressure from walking on top of it. They could replace coloured stones to create a colour palette with slightly differing tints, according to the requirements of the design, or when particular colours of stones were neither available nor abundant. No glass tesserae were found, a material normally used for mosaic wall decorations: this fact suggests that the tesserae in Amheida were intended for a floor.

\subsection{Raw Material (MMSN)}

The limestone and sandstone ${ }^{22}$ used for the tesserae seem to occur locally and, consequently, are relatively cheap, as they are accessible from many places near Trimithis. One of these places is Gebel Edmonstone (Qaret el-Mawhoub), an isolated rocky hill detached from the plateau (El Shazly et al. 1976: 11; Sefelnasr 2007: 97) and about $12 \mathrm{~km}$ from the city.

A small number of dark grey/black tesserae show a very thin banding of yellow sandstone on one face. Similarly, a few of the yellow tesserae include traces of a banding of red sandstone on one face. This indicates that the different colours derive from layers of sandstone in physical contact with each other in the outcrops (Fig. 20).

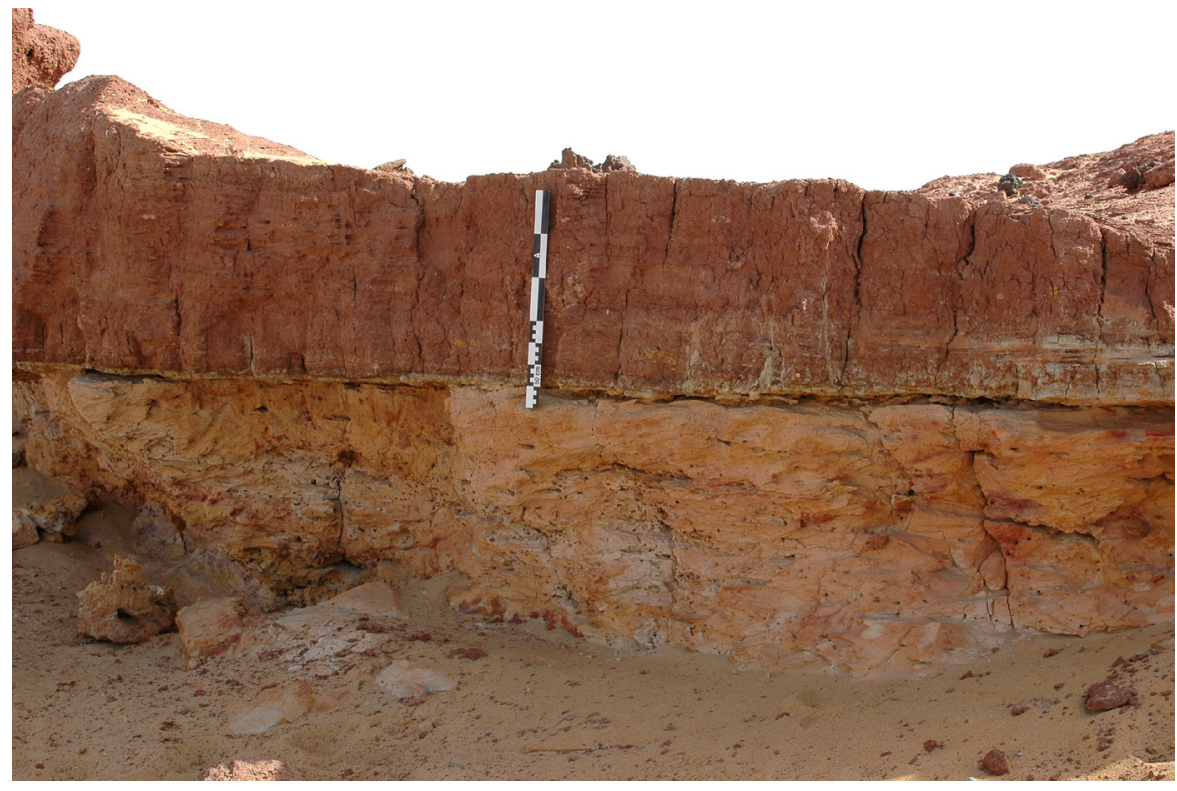

The exact locations and the owners of the quarries for the stone of the tesserae are so far unidentified ${ }^{23}$. Moreover, at present it is not possible to determine how the stone was commercialised. The raw material for the tesserae might simply derive from random cobbles - the result of weathering and detaching from the main rock outcrops - that were collected from the ground and may not necessarily have been extracted by an organised quarry enterprise or expedition.

22 Limestone and sandstone were actually the main building stones used in Egypt from Early Dynastic times onward and were also employed for statuary or other non-architectural applications (Harrell Storemyr 2009: 9).

23 The chemical composition of the stones used for the tesserae has not yet been determined, but it is hoped that this will be an object of future investigation. 
Together with the tesserae, some flakes from chipping and raw material, both from limestone and sandstone, were found in Room 30. The raw limestone pieces were slightly bigger in size and more abundant than the ones from sandstone (Fig. 21). It might be argued that the raw sandstone found here had already been reduced to smaller pieces to facilitate transport or that the sandstone tesserae were first produced somewhere else and only a final retouch was done in Room 30 .
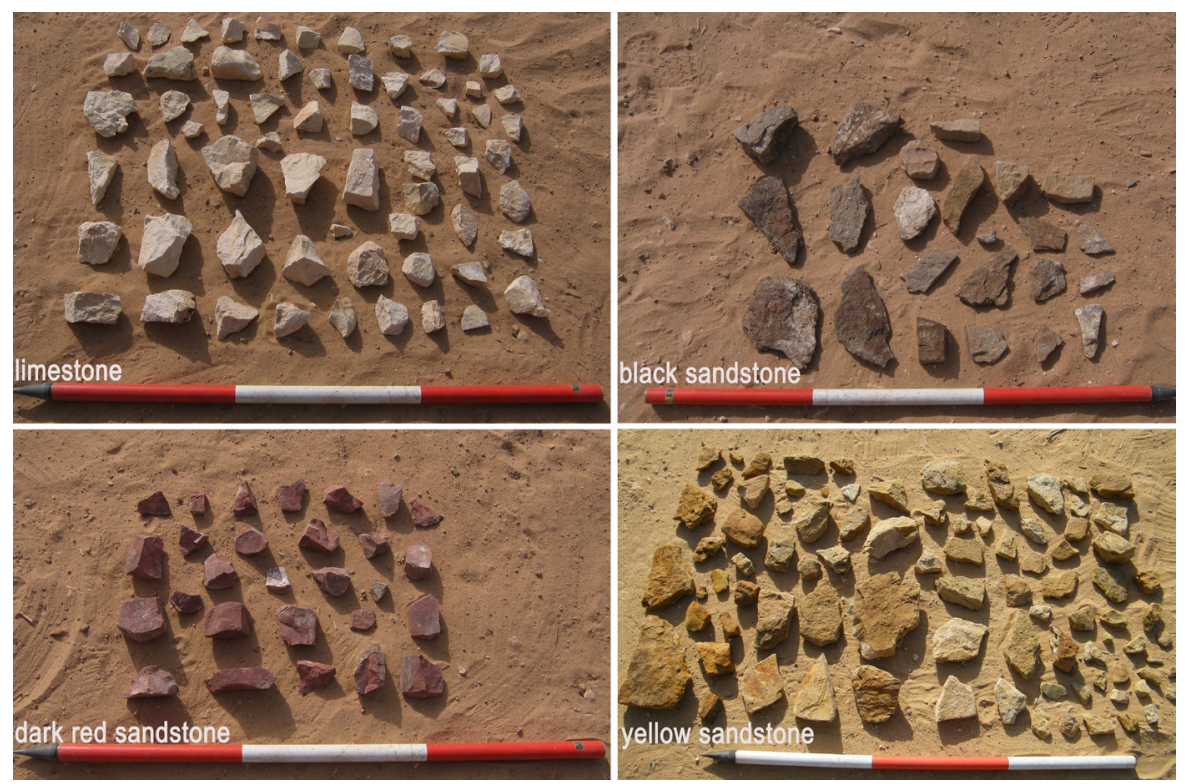

Diagnostic fragments and body sherds made of iron-rich fabric A1b and of Oasis Red Slip Ware (ORSW) found within DSU 49 can be interpreted as raw material and production waste from pottery tesserae chipping as well. One big semiconical mortarium made of limestone (inv. no. 15680, Fig. 22) found in DSU 49 , almost in the centre of Room 30, was probably awaiting its recycling into tesserae.

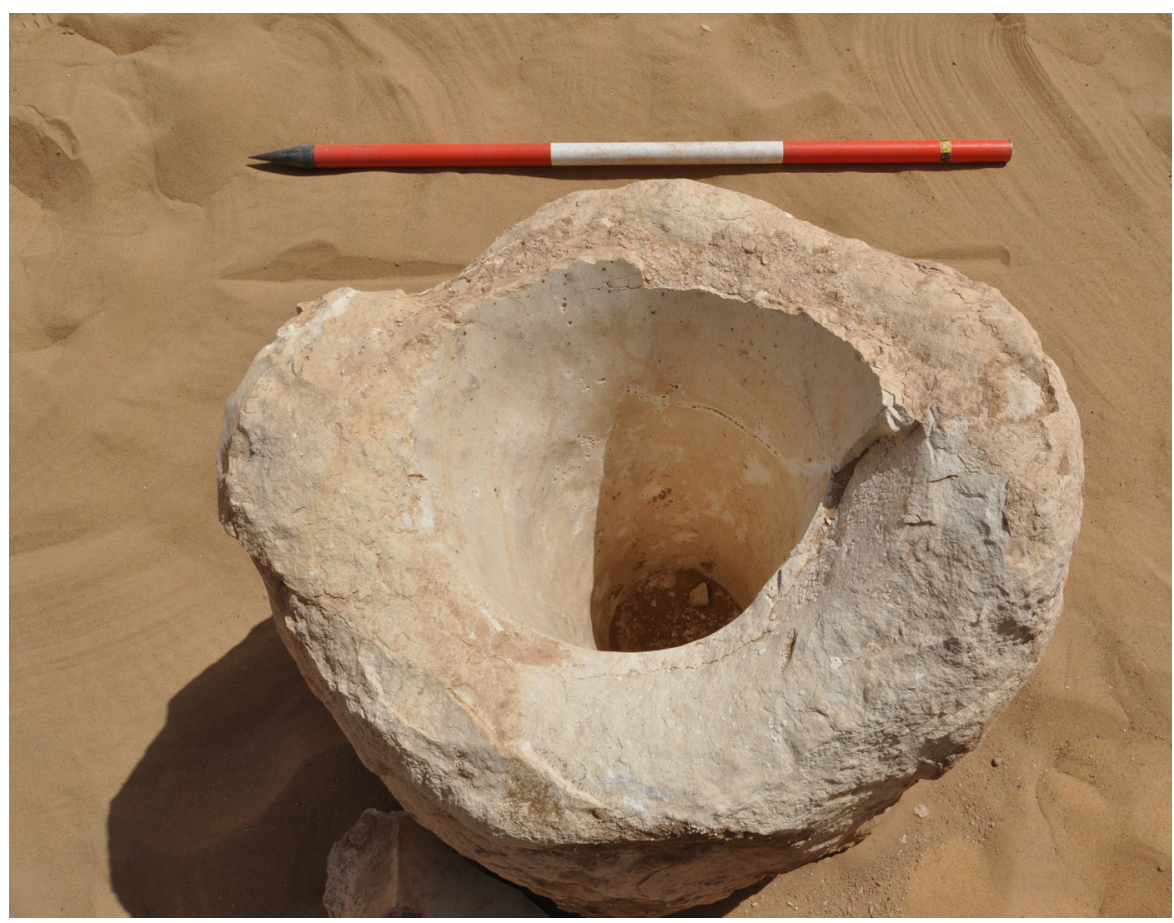

Figure 21

Raw material found within DSU 49 in Room 30: white limestone, yellow grey/black and red sandstone (graphic elaboration: MMSN).

Figure 22

The big semi-conical limestone mortarium found in Room 30, possibly used as raw material for white tesserae. 


\subsection{A Temporary Workshop (MMSN)}

It is not uncommon to find unused tesserae and production waste material close to the place where a mosaic was laid or had to be laid (Lichtenberger - Raja 2017: 1006; Wootton 2012b: 149). Together with the evidence presented above, it could be suggested that Room 30 was not only used as storage place, but as well as temporary production place - at least for some of the tesserae - where the activities of cutting, chipping and shaping the different raw materials were still ongoing when the entire restoration of the bathhouse suddenly came to a stop. As A. Lichtenberger and R. Raja noted, 'it is generally assumed that mosaic workshops were mobile' (Lichtenberger - Raja 2017: 1005) and that the mosaicists worked directly on site. Perhaps, due to their complexity, only the emblemata might have been pre-fabricated in workshops (Lichtenberger - Raja 2017: 1006).

Waste flakes were found spread in the central part of the room where fewer tesserae were found in DSU 49. White tesserae were concentrated mainly in the South-East corner of the room. They were not found tidily clustered, probably because they had been stored inside a container made of organic material that decayed or, more likely, they were simply piled in the corner of the room, without particular care. More careful storage is evident, for example, in the socalled 'House of the Tesserae' in Jerash (ancient Gerasa, Jordan), dating to the middle of the $8^{\text {th }}$ century AD and used as a temporary mosaic workshop. There, unused pre-fabricated tesserae were found stored in a trough, suggesting storage for ongoing long-term construction (Lichtenberger - Raja 2017: 1007). Pristine, second-hand and recycled tesserae were found in the already mentioned villa at Badminton Park, UK (middle to late $4^{\text {th }}$ century AD), in a pit containing also production waste that was located outside the south-eastern wall of a reception room equipped with a mosaic floor (Wootton 2012b: 149). From the position of the flakes and the tesserae in Room 30 at Trimithis one can hypothesise that a craftsman was chipping and refining the white limestone tesserae working in the middle of the room, from where he easily could have thrown the completed tesserae in the SE corner.

The other tesserae were concentrated in the opposite side of the room, in front of the northern and western walls, at about $1 \mathrm{~m}$ from the northern wall and $2 \mathrm{~m}$ from the western wall. The sandstone tesserae were probably already brought to Room 30 in convenient dimensions and/or shapes and were just retouched and adjusted there; the support for this hypothesis is the limited presence of sandstone working waste and raw material found in the room, compared to that of white limestone tesserae.

\subsection{Manufacturing tesserae (MMSN)}

Because the quantity of tesserae recovered in Room 30 is not enough to entirely pave any room of B6, it is possible that they were originally greater in number and were brought to another place within the building, as soon as they had been prepared. However, no tesserae were found in any other room of B6, so far. Another hypothesis might be that the tesserae were intended only for an emblema and that the rest of the floor was going to be paved with different material ${ }^{24}$

24 For example, a probably late $2^{\text {nd }}$ to early $3^{\text {rd }}$ century AD mosaic from the baths of Tyndaris, in Sicily, shows a central emblema made of tesserae, while the rest of the floor is paved with crustae irregularly shaped (Dunbabin 1999: 130-131 fig. 132). This mixed technique, however, is considered a local feature (Dunbabin 1999: 130). 
but, again, there is no archaeological support. The most likely hypothesis is that manufacturing had just started when the tesserae were left on site. In fact, on the basis of parallels with the abilities of rasp and file cutters of the $18^{\text {th }}$ century, J. DeLaine (1997: 181) calculated that about 20 tesserae per minute, or 14,400 tesserae per day ${ }^{25}$, can be produced by a single craftsman. This calculation is confirmed by modern mosaicists operating in Ravenna (Italy), where a school of mosaics is still active. The work organization was fundamental to make the tesserae manufacturing faster. After he has reduced the raw material to small pieces with a more or less squared shape, a good craftsman could make a single tessera with just one cut. Of course, more cuts and more time were necessary if the raw material was not conveniently shaped in advance ${ }^{26}$. According to this calculation, 17 hours would have been necessary to shape all the existing tesserae found in Room 30, circa 10 hours to chip only the white tesserae, of which the cutting waste is more abundant. Consequently, the tesserae found in Room 30 could have been prepared during a day and a half by a single craftsman or only in one day if more craftsmen were involved, calculating a 12-hour work day.

As the intended design of the mosaic will remain forever unknown, it is not possible to estimate with a fair amount of certainty how many hours would have been necessary until the final completion of the tesserae into a finished mosaic. On the basis of the calculations for the laying done by J. DeLaine and W. Wootton, however, a minimum of 1 second per tessera was necessary (DeLaine 1997: 181), extending to a maximum of 10 seconds (Wootton 2015: 266). This means that to process 20,430 tesserae, a single tessellarius - the craftsman in charge of laying the mosaic - would have needed up to 56.7 hours, depending on his experience and ability and on the complexity of the mosaic design.

Just as it is not possible to determine how many people ${ }^{27}$ were involved in the tesserae cutting process in Room 30, it is similarly not possible to conclude if the same person/persons was/were also the tessellarius/tessellarii.

According to Diocletian's Edict of Maximum Prices of AD 301 the daily salary of a tessellarius, including food, was 50 denarii, less than a musearius - who made wall mosaics and received 60 denarii per day. A wall painter (pictor parietarius) received 75 denarii per day and a painter (pictor imaginarius), 150 denarii ${ }^{28}$. However, this does not necessarily indicate that creating a mosaic floor was less expensive than painting a wall decoration, as this depended on the complexity of the work to do and the ability of the specialists involved. If the decorative motif was particularly complex, a pictor might have been involved in making the preparatory drawings, either with a direct or indirect participation in the final execution (Balmelle 2000: 580-581).

In the previously mentioned mosaic workshop in Jerash (see above paragraph 3.4), the archaeologists found also a metal tool, probably connected with the tesserae cutting ${ }^{29}$. The tool was recovered near the trough containing thousands

25 Estimating a 12-hour work day.

26 Marco Santi, personal communication on 29 November 2019.

27 The number of workmen depends also from the space available in Room 30 (circa 20 sq. m, see above). Calculating that a single workman needed at least $2 \mathrm{sq}$. $\mathrm{m}$ to avoid hindering other workmen, no more than 10 people could have been involved with tesserae production in Room 30 at the same moment.

28 Edictum Diocletiani et Collegarum de pretiis rerum venalium, 7, 1, 6-9.

29 https://www.livescience.com/60132-earthquake-reveals-mosaic-production-practices.html last access 19 September 2018; Rubina Raja, personal communication on 20 September 2018. 
of white, square tesserae with a side length of about $1 \mathrm{~cm}$ or a little more, stored pristine and unused, awaiting their usage (Lichtenberger - Raja 2017: 1005). The tool in question was presumably a marteline, a double-headed hammer with flat and sharp cutting edges. An example showing the use of such a tool is depicted on a fragment of a funerary relief from Ostia Antica, dated to the $4^{\text {th }}$ century AD and bearing the representation of a mosaic officina in which two men, seated on a stool or stone block, are engaged in shaping tesserae on anvils ${ }^{30}$.

In Room 30 no evidence for stone-cutting tools or items surely used as an anvil was found ${ }^{31}$. The very few metal objects deriving from the room were recovered underneath the walking surface layers and none can be connected with the tesserae manufacturing.

Working utensils might have been stored by the craftsmen in a different room of the building, but none of the rooms of B6 show the presence of such metal implements. This might mean that, even if the building was unexpectedly abandoned in the middle of its renovation, the workmen had the time to collect their tools and to partly empty the rooms. The reason of this abrupt abandonment is still unclear as there is no unquestionable evidence for a catastrophic natural event such as an earthquake at Trimithis (see below, Conclusions). Even if the tools were taken, obviously the value of the tesserae was not considered as high enough for their removal and re-utilisation in a different place and context.

\subsection{Speculating on a Mosaic that Never Was (MMSN)}

Up to the present, 50 bathhouses dating between the $1^{\text {st }}$ and the $6^{\text {th }}$ centuries $A D$ have been investigated in Egypt (Fournet et al. 2017: 451-523), 45 of which are generally classified in the scientific literature as Romano-Byzantine and can be dated from the late $3^{\text {rd }}$ to the mid-7th centuries AD (Fournet - Redon 2017: 279). $4^{\text {th }}$ century baths decorated with mosaic floors are rather uncommon. The northern bath in Karanis (Fayum, northern Egypt), for example, in use until the $4^{\text {th }}-5^{\text {th }}$ century AD, is paved with shelly limestone slabs (Castel 2009: 229). The monumental $4^{\text {th }}$ century bathhouse of Kom el-Dikka in Alexandria, covering an area of more than 5,000 sq. m, is paved with Proconnesian marble slabs in the frigidarium and with limestone in the porticos, while no preserved floors were found in the heated rooms (Kołątaj 1992: 91). In the West Baths of Clysma (at the head of the Gulf of Suez), dated to the $4^{\text {th }}-5^{\text {th }}$ century AD (or possibly later), the floors of Room c and Room $\mathrm{d}^{1}$ were paved with marble slabs (Fournet et al. 2017: 468 no. 58 (B331), with previous references).

Among the known baths in Egypt the only mosaic floor probably dating from the $3^{\text {rd }}-4^{\text {th }}$ century AD was recovered in the cold Room 2, near the seashore at Sheikh Zawyet (also spelled Cheikh Zouede), North Sinai and excavated in

30 The funerary relief (inv. no. 132) is stored in the "Museo Ostiense" in Ostia Antica. F. Pasini (Pasini 1978: tav. 3) considers the workmen just as tagliapietre (stonecutters). C. Robotti (1983: 313 planche CCI.1) believes that the men are mosaic makers. The interpretation of C. Robotti, agreed on by other scholars (for example Neira 2012: 104 fig. 2; Lichtenberger - Raja 2017: 1006-1007) is also supported by the fact that, beside the man to the right, there is a basket standing on the floor showing many small square elements that can, indeed, be interpreted as tesserae.

31 The limestone mortar found in this room might hardly have served for this purpose, because, due to its cylindrical shape and its size (height $63 \mathrm{~cm}$, diameter $51 \mathrm{~cm}$ ), it could not have offered a flat and comfortable working surface; moreover, the limestone itself might not have been sufficiently hard to resist to the cutting process. Usually anvils were metal made. Modern mosaicists from Ravenna (Italy) use a chisel-like blade (tagliolo, hardie or hardy) set into a block to easily cut tesserae from raw materials (Marco Santi, personal communication on 29 November 2019). Probably something similar was used also during Roman times, as the relief from Ostia may show and, in fact, the mosaic makers cut the tesserae on a small square element set into a block. 
1913 by J. Clédat (Fournet et al. 2017: 510 no. 86 (B46, N281), with previous references). It bore a Greek inscription saying that the bath was good, but no more details are given by its excavator (Meurice 2014: 207-208, reporting documents of the Compagnie C. Jonnart). At the same site, in a residential building, a large figured mosaic with mythological scenes was also found, according to H. Whitehouse (Whitehouse 2010: 1019) ${ }^{32}$ dating from the late $3^{\text {rd }}$ century AD, or to the Justinianic period (first half of the $6^{\text {th }}$ century AD) according to W.A. Daszewski (Daszewski 2005: 1146).

Finally, a mosaic with three figured panels is documented in the cold room of the public Roman bath of Psenemphaia (Kôm Trougah, in the Delta), but scholars are in disagreement about its date, as it is considered a $1^{\text {st }}$ to first half of the $2^{\text {nd }}$ century AD work by I. Nielsen (Nielsen 1990: 98 note 19, 114 note 141) and a $3^{\text {rd-4th }}$ century AD floor by T. Fournet et al. (Fournet et al. 2017: 506 no. 84 (B135, N285), with previous references).

Generally speaking, mosaic floors of any time were usually installed in the cold and dry parts of bath complexes, while the hot areas are frequently equipped with marble or limestone slabs ${ }^{33}$, or tiles. The humidity and the heat in the hot parts might cause tesserae to detach from their preparation layers. Consequently, any of the rooms in the cold or the dry part of B6 might have been suitable to be equipped with a mosaic floor. However, as mentioned above (Davoli 2017: 19 note 9), Room 24 and/or Room 26 have to be taken into consideration as the most likely rooms of the bath at Trimithis to be decorated with a mosaic floor. Room 26 is a recessed space in the north of Room 24. It was provided with benches and was probably used as a changing room or small meeting room (Davoli 2017: 197). Room 24, however, which was a central colonnaded space within the building, and which most probably had a social function, due to the presence of benches along the walls (Davoli 2017: 196), might be the best candidate to be decorated with a mosaic floor and Room 30, with its cache of tesserae, is situated close by.

The chromatic palette of the tesserae is limited to four colours ${ }^{34}$, the most common ones ${ }^{35}$. Nevertheless, as it has been argued that the tesserae production was in its early stages, it is also possible that the original intent might have been to add more colours.

It is not possible to figure out the decorative motif of a mosaic that never was. However, as a mere speculation, one might suggest a geometric pattern. These were very common for mosaics dating to the $4^{\text {th }}$ century $\mathrm{AD}$, in both private and public context. Examples are known from the Eastern Mediterranean areas, such as Greece and the island of Kos (for example, De Matteis 1997: 54), but also from other regions of the Roman Empire, like England (for example, Wootton 2012b: 145-168). From the beginning of the $4^{\text {th }}$ century AD, polychrome mosaic floors occur in entrance rooms and corridors of private houses in Ostia Antica with patterns mostly geometric in design (Hansen 1997: 119). Nonetheless, "in

32 From a stylistic point of view, it has to be considered closer to the Syro-Palestinian examples than to the ones from Egypt (Whitehouse 2010: 1019). The mosaic is exhibited in the museum of Ismailia (near Suez).

33 For example, floors made of stone slabs are suitable to pave the sospensurae (Giorgi 2012: 51 note 41).

$34 \mathrm{~A} 3^{\text {rd }}$ century mosaic AD from Alexandria, found broken in two in the site of Chatby, had geometrical motifs (lozenges filled with decorative elements) and a Greek inscription, diamond pattern and a guilloche motif. It was mainly black and white with few yellow and red tesserae in some places. The mosaic was not preserved. See Tkaczow 1993: 170-171 no. 138A).

35 Federico Guidobaldi, personal communication on 20 March 2019 
general, elaborate figurate scenes are not common on mosaics found in Egypt" (Whitehouse 2010: 1019).

Even if the tesserae found in Amheida were never used, it is important to stress that these findings are the first evidence for a mosaic floor in the Western Oasis and are therefore unique so far, not only for the Western Desert, but for Egypt as a whole, especially in this time period.

\section{Conclusions (MMSN, SP)}

Mosaic floors were introduced in Egypt during the Hellenistic period, around the end of the $4^{\text {th }}$ or the start of the $3^{\text {rd }}$ century $\mathrm{BC}$, in both public and private buildings. However, this paving technique was never in widespread use in Egypt during Hellenistic and Roman times and was employed mainly in the city of Alexandria ${ }^{36}$, in its hinterland and in the Delta (Whitehouse 2010: 1017), areas with a more Hellenized population (Daszewski 2000: 43). In Upper Egypt, among the very few tesserae mosaics found in situ, one - dated to the late Ptolemaic period (second half of the $1^{\text {st }}$ century $\mathrm{BC}$ ) - was recovered in a circular tholos in a bath at $\mathrm{Hu}$ (Hiw, on the left bank of Nile river, near Nag Hammâdi; Whitehouse 2010: 1018, with previous references). Another, of a Late Roman date, is known from Antinoupolis, with a figured emblema badly damaged (Daszewski 2005: 1146; Whitehouse 2010: 1019, with previous references).

On the basis of this premise, the discovery of about 20,430 pristine mosaic tesserae in a room of bath complex B6, in a late $4^{\text {th }}$ century $\mathrm{AD}$ context, is interesting and surprising because it represents, so far, an unicum in the Western Desert (see also Davoli 2017: 206) where, until now, no mosaic floors were documented. Moreover, the presence of production waste and raw material, found together with the tesserae, indicates that these last where shaped inside the building where, most likely, the mosaic had to be laid and that, consequently, a temporary workshop was created inside B6. Temporary workshops were identified all over the Mediterranean, dating from Roman times onwards, however this is the first case known in Egypt and makes the discovery even more impressive.

A luxury and refined pavement was going to be laid out with coloured stone tesserae and a small percentage - less than $1 \%$ - of pottery tesserae, demonstrating that a considerable economic investment was planned for the renovation and embellishment of the interior design of the bath complex. The tesserae were made of local white limestone and yellow, red and grey sandstone - easily available in nature. It is not possible to determine how the final design of the mosaic was to be, nor to establish if the colours were going to be more than four as the tesserae manufacturing process was just started, as indicated by the number of tesserae found and by the calculation of the time necessary for their manufacturing, based on the ability of rasp and file cutters of the $18^{\text {th }}$ century and of modern mosaicists from Ravenna (Italy).

36 For instance, the mosaics dating to the Early Roman period ( $1^{\text {st }}$ to $3^{\text {rd }}$ centuries AD) from building alpha, called also the "Villa of the Birds", in the residential district identified at Kom el-Dikka, found below a Late Roman/Byzantine ( $4^{\text {th }}$ to $7^{\text {th }}$ centuries AD) district which had residential, commercial and industrial purposes (Kołątaj et al. 2007: 6-15). Other sites in Alexandria where Early Roman mosaics were found include the area of the so called 'Scuola Scozzese', near the Eastern Port/Caesareum, with a mosaic floor with polychrome geometric design dated to the $1^{\text {st }}-2^{\text {nd }}$ century AD (Tkaczow 1993: 142 no. 101) and the site of Chatby (north of Abukir street) where in 1931 and in 1932-1934 fragments of two mosaics dated to the $3^{\text {rd }}$ century AD were recovered. One had a geometrical pattern and a Greek inscription and the other showed a geometrical motif of white and black tesserae (Tkaczow 1993: 170-171 no. 138A). For other sites in Alexandria with mosaic finds see Tkaczow 1993: 333 "mosaic floors" and Guimier-Sorbets 2019. 
A terminus post quem for the tesserae manufacturing and for the time period of the final renovation of the bath is given by six ostraka recovered in DSU 56 - a rubble layer that might have been a walking surface before the mortar plaster FSU 76 was prepared inside Room 30 - dated by R. Ast and R.S. Bagnall between 350-370 AD (Ast - Bagnall 2016: 123-124 no. 473, 129 no. 486, 162 no. $568,162-163$ no. 569, 163 no. 570, 250 no. 805 ). The tesserae were prepared soon after this date, as no later ostraka were found in the entire building.

Unfortunately, the refurbishment of the bath was interrupted and never completed, the tesserae remained unused and the entire complex was abruptly abandoned in the middle of a major ongoing restoration.

Many questions about the renovation of B6 remain without satisfactory answers. For example, in the present state of our knowledge it is inexplicable why a mosaic was the paving technique chosen among others to embellish the floor of one or more rooms of B6, since mosaics, as stated above, were, in general, not particularly spread in Egypt and, so far as our present knowledge goes, were totally absent in Dakhla Oasis. In the cold and dry rooms of the building there are mud floors, while in the hot rooms there are prints or a few preserved remains of limestone slabs, but, as the renovation was left incomplete, and as the baked brick structures were so badly robbed, it is not possible to determine how the finished decoration work would have turned out, just as it is impossible to establish if this decorative work might have had any social, cultural and political implication. However, a great effort was already spent on the on-going renovation, perhaps using public money under the local governor's control (Davoli 2017: 195 note 10).

The abandonment of B6 and, in general, of the entire city of Trimithis, might have been provoked by a series of linked factors, natural/climatic and/or economical that are not unquestionable at the moment and still under discussion, but that might be clarified by further excavation ${ }^{37}$.

\section{Acknowledgments}

The authors are grateful to R. S. Bagnall and P. Davoli for allowing them to publish this article and for their comments. M. M. S. Nuovo is also thankful to C. M. Bongiorno, F. Guidobaldi, R. Palmer, R. Raja, M. Santi and F. Yegül for kindly sharing information, comments and opinions.

37 For example, in B1 shifting and restoration of some walls are visible in Room 6, 11, 13 and 14 (Davoli - Bagnall 2015: 89 note 20), but no unquestionable damages caused by earthquakes. As well, there is no evidence, so far, that the tsunami and the earthquake that destroyed the coast of Alexandria in 365 $\mathrm{AD}$ had any impact on the Western Desert oasis and on Trimithis. For the ancient sources mentioning the earthquake/tsunami of 21 July 365 and for discussions on this topic see Jacques - Bousquet 1984: 423-461, Leppelley 1984: 463-491 and Guidoboni 1994: 267-274. 


\section{Bibliography - Kaynaklar}

Allen - Fulford 2004

Aravecchia et al. 2015

Ast - Bagnall 2015

Ast - Bagnall 2016

Bagnall 1997

Bagnall - Ruffini 2012

Bagnall - Kaper 2015

Bagnall et al. 2017

Balmelle 2000

Boozer 2015

Brookes 1994

Caputo 2020

Castel 2009

Cribiore - Davoli Ratzan 2008

Daszewski 2000

Daszewski 2005

Davoli 2012

Davoli 2015a

Davoli 2015b

Davoli 2017

Davoli - Cribiore 2010

Davoli - Bagnall 2015

DeLaine 1997

De Matteis 1997
J. R. L. Allen - M. G. Fulford, "Early Roman mosaic materials in southern Britain, with particular reference to Silchester (Calleva Atrebatum): a regional geological perspective”, Britannia 35, 9-38.

N. Aravecchia - T. L. Dupras - D. Dzierzbicka - L. Williams, "The church at Amheida (ancient Trimithis) in the Dakhleh Oasis, Egypt. A bioarchaeological perspective on an Early Christian mortuary complex", Bioarchaeology of the Near East 9, 21-43.

R. Ast - R. S. Bagnall, "New Evidence for the Roman Garrison of Trimithis”, Tyche 30, 1-4.

R. Ast - R. S. Bagnall, Amheida III. Ostraka from Trimithis, vol. 2, Texts from the 2008-2013 seasons, with contributions by C. Caputo and R. Cribiore, New York.

R. S. Bagnall, The Kellis Agricultural Account Book (P. Kell. IV Gr.96), Oxford.

R. S. Bagnall - G. R. Ruffini, Amheida I. Ostraka from Trimithis, vol.1, Texts from the 2004-2007 seasons, New York.

R. S. Bagnall - O. E. Kaper, "Introduction”, R.S. Bagnall - N. Aravecchia - R. Cribiore - P. Davoli - O. E. Kaper S. McFadden (eds.), An Oasis City, New York, 1-10.

R. S. Bagnall - C. Caputo - R. Casagrande Kim - I. Soto, "New evidence from ostraca for the dating of the $4^{\text {th }}$ century CE ceramic assemblages", BCE 27, 195-211.

C. Balmelle, "Les artisans mosaïstes dans l'Antiquité", H. Lavagne - É. da Balanda - A. Uribe Echeverría (eds.), Mosaïque. Trésor de la latinité. Des origines à nos jours, Quetigny, Paris, 579-581.

A. L. Boozer, Amheida II. A late Romano-Egyptian house in the Dakhla Oasis: Amheida House B2, with contributions from Douglas V. Campana, Angela Cervi, Pam J. Crabtree, Paola Davoli, Delphine Dixneuf, David Ratzan, Giovanni Ruffini, Ursula Thanheiser, Johannes Walter, New York.

I. A. Brookes, "Geomorphology and Quaternary Geology of the Dakhla Oasis Region”, Egypt, Quaternary Science Reviews 12, 29-552.

C. Caputo, The House of Serenos, Part I: The Pottery (Amheida V), New York.

G. Castel, "Bain nord de Karanis", M.-F. Boussac Fournet - B. Redon (eds.), Le bain collectif en Égypte, Études urbaines 7, Le Caire, 229-245.

R. Cribiore - P. Davoli - D. M. Ratzan, “A teacher's dipinto from Trimithis (Dakhleh Oasis), JRA 21, 170-191.

W. A. Daszewski, “La mosaïque en Égypte”, H. Lavagne - É. da Balanda - A. Uribe Echeverría (eds.), Mosaïque. Trésor de la latinité. Des origines à nos jours, Paris, 43-45.

W. A. Daszewski, “Egypt, birds and mosaics”, H. Morlier (ed.), LMGR IX, vol. 2, Roma, 1143-1152.

P. Davoli, “Amheida 2007-2009. New Results from the Excavations”, R. S. Bagnall - P. Davoli - C. Hope (eds.), The Oasis Papers 6, Proceedings of the Sixth International Conference of the Dakhleh Oasis Project, DaklehOasis Project Monographs 6, Oxford, 263-278.

P. Davoli, “Amheida in its surroundings”, R.S. Bagnall - N. Aravecchia - R. Cribiore - P. Davoli - O. E. Kaper - S. McFadden (eds.), An Oasis City, New York, 11-21.

P. Davoli, "The baths of Trimithis", R.S. Bagnall - N. Aravecchia - R. Cribiore - P. Davoli - O. E. Kaper - S. McFadden (eds.), An Oasis City, New York, 76-86.

P. Davoli, “A new public bath in Trimithis (Amheida, Dakhla Oasis)”, B. Redon (ed.), Collective Baths in Egypt 2. New Discoveries and Perspectives, Études urbaines 10, Le Caire, 193-220.

P. Davoli - R. Cribiore, "Una scuola di greco del IV secolo d.C. a Trimithis (Oasi di Dakhla, Egitto)”, M. Capasso (ed.), Leggere Greco e Latino fuori dai confini del mondo antico, Atti del I Congresso Nazionale dell'Associazione Italiana di Cultura Classica, Lecce 10-11 maggio 2008, Lecce, 73-87.

P. Davoli - R. S. Bagnall, “Two houses”, R.S. Bagnall - N. Aravecchia - R. Cribiore - P. Davoli - O. E. Kaper - S. McFadden (eds.), An Oasis City, New York, 86-104.

J. DeLaine, The baths of Caracalla. A study in the design, construction, and economics of large-scale building projects in imperial Rome, JRA Suppl. 25, Portsmouth.

L. M. De Matteis, "La produzione musiva coa in età tardoantica: indirizzi di ricerca", S. Isager - B. Poulsen (eds.), Patron and Pavements in Late Antiquity, Odense, 51-64. 
Dunbabin 1999

El Shazly et al. 1976

Fournet et al. 2017

Fournet - Redon 2017

Giorgi 2012

Guidoboni 1994

Guimier-Sorbets 2019

Hansen 1997

Harrell - Storemyr 2009

Jacques - Bousquet 1984

Kaper 2015

Kenfield 1997

Kołątaj 1992

Kołątaj et al. 2007

Kucera 2016

Laudenbach 2015

Lepelley 1984

Lichtenberger - Raja 2017

Meurice 2014

Merrony 2013

Neira 2012

Nielsen 1990

Pasini 1978

Paver - Pretorius 1954

Report 2004

Robotti 1983

Sefelnasr 2007
K. M. D. Dunbabin, Mosaics of the Greek and Roman World, Cambridge.

E. M. El Shazly - I. A. El Kassas - H. El Amin - A. A. Abdel Megid - M. A. Abdel Hady - A. B. Salaman - M. M. El Shazly, Geology of Kharga-Dakhla Oases Area, Western Desert, Egypt, from Landsat-1 satellite images, Remote Sensing Center, Academy of Scientific Research and Technology, Cairo.

T. Fournet - B. Redon - M. Vanpeene, "Catalogue of the Roman and Byzantine Baths of Egypt", B. Redon (ed.), Collective Baths in Egypt 2, New Discoveries and Perspectives, Études urbaines 10, Le Caire, 451-523.

T. Fournet - B. Redon, "Romano-Byzantine Baths of Egypt. The Birth and Spread of a Little-Know Regional Model”, B. Redon (ed.), Collective Baths in Egypt 2, New Discoveries and Perspectives, Études urbaines 10, Le Caire, 279-321.

E. Giorgi, I bagni romani di Bakchias. La storia dell'edificio e l'evoluzione dell'impianto urbano, Imola, La Mandragola.

E. Guidoboni, Catalogue of the ancient earthquakes in the Mediterranean area up to the $10^{\text {th }}$ century, with the collaboration of A. Comastri and G. Traina, Roma, Istituto Nazionale di Geofisica.

A. S. Guimier-Sorbets, Mosaïques d'Alexandrie. Pavements d'Égypte grecque et romaine, Alexandria.

S. L. Hansen, "The embellishment of Late-antique domus in Ostia and Rome”, S. Isager - B. Poulsen (eds.), Patron and Pavements in Late Antiquity, Odense, 111-124.

J. A. Harrell - P. Storemyr, "Ancient Egyptian quarries-an illustrated overview”, Geological Survey of Norway Special Publication 12, 7-50.

F. Jacques - B. Bousquet, "Le raz de marée du 21 julliet 365. Du cataclysme local à la catastrophe cosmique", MEFRA 96, 423-461.

O. E. Kaper, “The sacred landscape”, R.S. Bagnall - N. Aravecchia - R. Cribiore - P. Davoli - O. E. Kaper S. McFadden (eds.), An Oasis City, New York, 21-28.

J. F. Kenfield, "Mosaics", E. Hostetter - T. Noble House (eds.), The Romano-British Villa at Castle Copse, Great Bedwyn, Bloomington and Indianapolis, 169-193.

W. Kołątaj, Alexandrie VI. Imperial baths at Kom el-Dikka, Varsovie, Park.

W. Kołątaj - G. Majcherek - E. Parandowska, Villa of the Birds. The excavation of the Kom al-Dikka mosaics, Cairo, New York.

P. Kucera, "al-Qasr: the Roman Castrum of Daklheh Oasis", R.S. Bagnall - P. Davoli - C.A. Hope (eds.), The Oasis Paper 6, Oxford, 305-316.

B. Laudenbach, Strabon Geographie. Tome XIV: Livre XVII, 1ere partie (L'Égypte et l'Éthiopie nilotique), Paris.

C. Lepelley, “L'Afrique du Nord et le prétendu séisme universel du 21 Juillet 365”, MEFRA 96, 463-491.

A. Lichtenberger - R. Raja, "Mosaicists at work: the organization of mosaic production in Early Islamic Jerash", Antiquity 91, 358, 998-1010.

C. Meurice, Jean Clédat en Égypte et en Nubie (1900-1914), Le Caire.

M. Merrony, Socio-Economic Aspects of Late Roman Mosaic Pavements in Phoenicia and Northern Palestine, BAR International Series 2530, Oxford.

L. Neira, "Unique representation of a mosaic craftsman in a Roman pavement from the Ancient Province Syria”, JMR 5, 103-113.

I. Nielsen, Thermae et Balnea. The Architecture and Cultural History of Roman Public Baths I, Aarhus.

F. Pasini, Ostia Antica. Insulae e classi sociali. I e II secolo dell’Impero, Roma.

G. L. Paver - D. A. Pretorius, Report on hydrogeological investigations in Kharga and Dakhla Oases, Heliopolis, Publications de l'Institut du Desert d'Egypte.

Excavations at Amheida, 2004 (unpublished archeological report with no authors' names), http://www.amheida. org/inc/pdf/Report2004.pdf.

C. Robotti, "Una sinopia musiva negli scavi nuovi di Pompei”, R. Ginouvès (ed.), Hommages H. Stern, Paris, 311-314.

A. M. Sefelnasr, Development of groundwater flow model for water resources management in the development areas of Western Desert, Egypt, unpublished PhD dissertation submitted to the Faculty of Natural Science III of the Martin Luther University, Halle-Wittenberg. 
Tkaczow 1993

Waldhoff et al. 2008

Whitehouse 2010

Wootton 2012a

Wootton $2012 b$

Wootton 2015
B. Tkaczow, The Topography of Ancient Alexandria (An Archaeological Map), Varsovie, Wydawnictwo 'Park'.

G. Waldhoff - O. Bubenzer - A. Bolten - W. Koppe - G. Bareth, "Spectral analysis of Aster, Hyperion, and Quickbird data for geomorphological and geological research in Egypt (Dakhla Oasis, Western Desert)", The International Archives of the Photogrammetry, Remote Sensing and Spatial Information Sciences, XXXVII, Part B8.

H. Whitehouse, "Mosaics and painting in Graeco-Roman Egypt", A. B. Lloyd (ed.), A companion to Ancient Egypt, Malden and Oxford, 1008-1031.

W. Wootton, "Making and meaning: the Hellenistic mosaic from Tel Dor", AJA 116, 2, 209-234.

W. Wootton, "Mosaic production in $4^{\text {th }}$-c. Britain: materials, making and makers at Badminton Park", JRA suppl. 92, 145-168.

W. Wootton, "Figuring out of the facts: calculating mosaic labour times in $4^{\text {th }}-$ c. A.D. Britain", JRA 28, 261282. 
